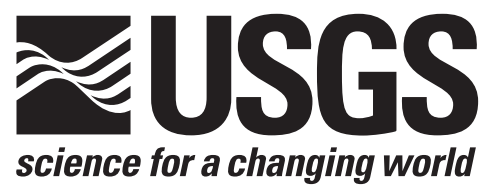

\title{
Springs on and in the vicinity of Mount Hood volcano, Oregon
}

By Manuel Nathenson

2004

Open-File Report 2004-1298

U.S. Department of the Interior

U.S. Geological Survey 


\section{Abstract}

Chemical and isotopic data are presented for nonthermal, thermal, and slightly thermal springs and drill holes and fumaroles on Mount Hood, Oregon. Temperatures of nonthermal springs on Mount Hood decrease with elevation and are similar to air temperatures from nearby weather stations. Dissolved constituents in nonthermal springs generally increase with spring temperatures and reflect weathering of volcanic rock from the action of dissolved carbon dioxide. Isotopic contents of nonthermal springs follow a local meteoric water line and generally become lighter with elevation. Some nonthermal springs at low-elevation have light values of isotopes indicating a high-elevation source for the water. Three hydrothermal systems have been identified on Mount Hood. Swim Warm Springs is interpreted to have a source water that boiled from $187^{\circ} \mathrm{C}$, re-equilibrated at $96^{\circ} \mathrm{C}$, and then mixed with nonthermal water to produce the range of compositions found in various springs. The Meadows Spring is interpreted to have a source water that boiled from $223^{\circ} \mathrm{C}$, re-equilibrated at $94^{\circ} \mathrm{C}$, and then mixed with nonthermal water to produce the range of compositions found in the spring over several years. Both systems contain water that originated as precipitation at higher elevation. The summit fumaroles have gas geothermometer temperatures generally over $300^{\circ} \mathrm{C}$, indicating that they are not the steam discharge from the Swim and Meadows hydrothermal systems. Representative values of thermal discharge for the three hydrothermal systems are $10 \mathrm{MW}_{\mathrm{t}}$ for the fumaroles, 2.2 $\mathrm{MW}_{\mathrm{t}}$ for Swim, and 1.9 $\mathrm{MW}_{\mathrm{t}}$ for the Meadows and Cascade springs.

\section{Introduction}

The Mount Hood edifice occupies a long-lived focus of andesitic volcanism that has been active for the past 1.5 m.y. (Wise, 1969; Scott and others, 1997). The present-day cone is made up of lava flows and volcaniclastic deposits. Most volcanic activity in the past $50 \mathrm{kyr}$ has consisted of the growth and collapse of lava domes and the eruption of lava flows on the summit and upper flanks (Scott and others, 1997). Three eruptive periods have been recognized in late-glacial through Holocene time (Crandell, 1980; Cameron and Pringle, 1986, 1987; Scott and others, 1997): 1) Polallie, 20 -13 ka; 2) Timberline, 15001700 yr B.P. (1950 C.E. is present); and 3) Old Maid, 1760-1810 C.E. Minor historical activity has been reported for Mount Hood in 1859, 1865, and 1907 C.E. (Crandell, 1980; Scott and others, 1997). The Polallie eruptive period coincides with and postdates the last major Pleistocene glacial advance in the area, called the Evans Creek advance by Scott and others (1997). Between Polallie and Timberline periods, the Parkdale basaltic andesite flow (7680 yr B.P.) was erupted low on the volcano's north flank, in the upper Hood River valley (Crandell, 1980). The Old Maid eruptive period probably commenced with the emplacement of a near-summit dacite dome, the remnant of which still can be seen as Crater Rock high on the volcano's south flank. One of Mount Hood's thermal features is the fumarolic area near Crater Rock.

Springs on Mount Hood were sampled by Wollenberg and others (1979); however, the reported analyses were incomplete, and inspection of topographic maps indicates that there are more springs than were reported on by Wollenberg and others (1979). This study was initiated to visit additional springs and assess if there were additional sources of thermal 
water beyond that identified at Swim Warm Springs and the summit fumaroles. After finding anomalous specific conductance and temperature at the Meadows Spring and finding that there were springs not shown on the topographic maps (but usually located where a stream started on the map), an attempt was made to find springs and to measure specific conductance of streams to locate other anomalies (Table 1 and Figure 1). Although a significant amount of the mountain was visited to look for water with significant conductivity anomalies, it is very likely that there are additional unidentified springs on the mountain.

In studying the characteristics of springs, it is important to be clear on the terminology (Nathenson and others, 2003). A special class of springs known as thermal springs are ones "whose water has a temperature appreciably above the mean annual temperature of the atmosphere in the vicinity of the spring (Meinzer, 1923, p. 54.)." Meinzer does not define appreciable. Meinzer (p. 55) goes on to state that: "Nonthermal springs may be divided into (1) those whose waters have temperatures approximating the mean annual temperatures of the atmosphere in the localities in which they exist, and (2) those whose waters are appreciably colder." The second group of nonthermal springs are cold springs. Waring (1965, p. 4) agrees with Meinzer that any spring that "is noticeably above the mean annual temperature of the air at the same locality may be classed as thermal" but uses $15^{\circ} \mathrm{F}\left(8.3^{\circ} \mathrm{C}\right)$ above mean annual temperature of the air to define thermal springs in the United States. Reed (1983, p.2) in the U.S. Geological Survey's assessment of lowtemperature geothermal resources of the United States uses a minimum temperature function that is $10^{\circ} \mathrm{C}$ above the mean annual temperature at the surface and increases with depth by $25^{\circ} \mathrm{C} / \mathrm{km}$ to define low-temperature geothermal resources. In most situations, the question of using a numerical temperature criterion for thermal springs is not important, because measured temperatures are sufficiently anomalous. In the Cascade Range, however, large quantities of cold ground water mix with thermal water making the magnitude of the temperature anomalies very small (e.g. Nathenson, 1990). To cover this situation, the term slightly thermal springs is introduced for springs that do not meet the numerical criterion of Reed (1983), but have temperatures greater than nonthermal springs in the area and usually also have dissolved constituents normally found in thermal waters (Nathenson and others, 2003).

Nonthermal springs were sampled to provide temperature, specific conductance, and chemistry data to differentiate nonthermal springs from slightly thermal and thermal springs. An additional topic is the identification of salt applied to the Palmer snow field that was detected in some nonthermal springs. Isotopic data for nonthermal springs make it possible to develop isotope-elevation relationships to estimate recharge elevations for deeply circulating nonthermal springs and thermal springs. Gas analyses from the literature and unpublished data are presented to estimate reservoir temperatures for the summit fumaroles.

\section{General characteristics of springs}

In order to discuss temperature data for springs, data for mean annual air temperatures from weather stations (National Oceanic and Atmospheric Administration, $1997 \mathrm{a}$ and b) within a two degree of latitude by two and half degree of longitude block centered on Mount Hood (Figure 2) are plotted versus station elevation (Figure 3). The mean annual air temperatures are the "normal" values for the period 1961 to 1990.

(Because normal values are not listed in the tables, they are obtained from the published data 
tables by subtracting the listed departure from normal from the mean annual temperature for the year of the table.) Air temperatures are mostly determined by station elevation (Figure 3 ) with some variability about this relationship. Using least-squares correlation with temperature as the dependent variable, the slope of the correlation line shown in Figure 3 is $-0.00437 \pm 0.00038{ }^{\circ} \mathrm{C} / \mathrm{m}$ and the intercept is $11.6 \pm 0.2^{\circ} \mathrm{C}$ (standard errors of the mean).

Temperatures of springs in the nonthermal and Palmer springs groups are generally cooler than air temperatures (Figure 3) though close enough to air temperatures to be categorized as nonthermal springs rather than cold springs. Crystal, Lolo Pass, and Rogers springs are cooler than the trend of other nonthermal springs. Crystal, Lolo Pass, and Rogers springs have relatively high flow rates (Table 1), and their lower temperatures could reflect high elevation recharge with flow channeling into discrete channels in the subsurface preventing solar heating as the water flows to lower elevations. Parkdale Cold Spring is in the vicinity of Crystal and Rogers springs and has a relatively high flow rate, but its temperature follows the trend of other nonthermal springs. Temperatures for the Meadows Spring (but not the East Meadows Spring) and the Cascade Spring are higher than the air temperature-elevation line and will be shown below to have a component of thermal water. Temperatures for Swim Warm Springs are too high to plot on the scale of Figure 3.

Specific conductance of the nonthermal springs is linearly related to the measured spring temperature (Figure 4). This behavior reflects weathering of volcanic rock by the action of dissolved carbon dioxide (e.g. Nathenson and Thompson, 1990). Palmer and Still Creek springs and Phlox Point spring box are above the trend, and their behavior is discussed below with their chemistry. Meadows, East Meadows, and Cascade springs are also above the trend and will be shown below to have a component of thermal water.

Data for water chemistry of previously collected samples and those collected in this study are given in Tables 2 and 3, and locations are given in Figure 5. There are some concerns regarding the quality of the early data, and the more modern data will generally be used. However, the older data are included so that unpublished isotopic data can be made available. For the data set in Wollenberg and others (1979), only nonthermal water samples with isotopic data have been included. The data for some of the nonthermal springs are shown in a modified Schoeller diagram in Figure 6. Amounts of chloride and sulfate are about what one would expect in precipitation (e.g. Nathenson and Thompson, 1990). The major anion is bicarbonate from dissolved carbon dioxide reacting with minerals in volcanic rock to produce dissolved silica and cations (Nathenson and Thompson, 1990). Thus the variation of specific conductance with temperature reflects the variation of bicarbonate concentration with temperature.

Data for the rest of the nonthermal springs are given in Figure 7 along with the spring tributary to the Zigzag River for reference and the Salmon River sampled near Palmer Springs. Chloride in these springs range from 3.7 to $17.1 \mathrm{mg} / \mathrm{L}$, well above what would come from precipitation. The Timberline Ski area applies approximately $500,000 \mathrm{~kg}$ of sodium chloride to the Palmer snowfield and associated areas between an elevation 1800 and $2600 \mathrm{~m}$ primarily during the summer months to condition snow (Mt. Hood National Forest, 1999, 2000, 2001). The data for the Salmon River at the Palmer Springs (just above Timberline Trail) collected in August, 1999 reflect snow melt including applied sodium chloride. During that visit, snow covered additional springs in the area that feed the Salmon River, and only the main Palmer Spring was visible and sampled. The concentrations of sodium and chloride were much lower in the spring sample than in river water. Concentrations of silica and other constituents in the Salmon River samples, except for sodium and chloride, are much lower than in spring samples (Figure 7) as one would expect 
from passage of water over a stream bed in contrast to reaction with rock underground. Given the appearance of anomalous chloride and associated sodium in the Palmer Spring, the data for the other springs shown in Figure 7 and comparison with data shown in Figure 6 for other springs indicates that the source of chloride in the Still Creek and Phlox Point springs is probably also snow melt with applied sodium chloride. Figure 8 shows sodium versus chloride for these springs along with the data for the Salmon River and Zigzag River and Cloud Cap Campground springs for reference. One model is that both sodium and chloride found in the samples are produced by dilution. Even though sodium should be added by the reaction of dissolved carbon dioxide with minerals in the subsurface, this model assumes that such reaction does not take place. Another model is that water with dissolved sodium chloride mixes with a normal spring water such as that found in the spring near the Zigzag River. Most of the samples appear to follow the dilution model. The Still Creek spring sample has a lower sodium than predicted by the dilution model and would seem to require sodium exchange for calcium and/or magnesium. Additional features at Palmer Springs found in 2001 were measured for temperature and specific conductance (Table 1), and their behavior is reasonably similar. The Salmon River in 2001 only contained water from these various features with the channel above Palmer Springs completely dry. Thus the spring-fed flow in 2001 of $7 \mathrm{~L} / \mathrm{s}$ of $81.5 \mu \mathrm{S} / \mathrm{cm}$ water is a small fraction of the flow in 1999 of around $100 \mathrm{~L} / \mathrm{s}$ of $\approx 400 \mu \mathrm{S} / \mathrm{cm}$ of snow melt.

Additional information on the characteristics of nonthermal springs and background for discussion of thermal springs is provided by the isotopic data. Figure 9 presents the light-stable isotope data (reported as per mil deviations from VSMOW (Gonfiantini, 1978)). One snow sample is beyond the range of the plot. The intercept of the meteoric water line has been adjusted to best fit the data not including the snow samples or the sample from the Pucci well. The data from Wollenberg and others (1979) are shown as a separate group, and they are consistent with data from this study. The data are plotted versus elevation in Figures 10 and 11. The isotopic composition of precipitation decreases (more negative values) with increasing elevation (Dansgaard, 1964). Assuming that some springs are recharged at elevations only somewhat above their discharge elevations, the samples having the highest deuterium and oxygen-18 values for a given elevation are used to define the lines for local precipitation (fitted by eye) in Figures 10 and 11 (Ingebritsen and others, 1992; Rose and others, 1996). Part of the fitting process involves making the lines consistent with the local meteoric water line of Figure 9. The slope of the oxygen-18 line is $-1.7 \%$ o $/ \mathrm{km}$, somewhat less than the value of $-2.3 \% \mathrm{~km}$ found by Rose and others (1996) for the area north of Lassen Peak but close to the slope found for Mount Shasta of $-1.4 \% / \mathrm{km}$ (Nathenson and others, 2003). The snow samples are lighter than the line based on the spring samples, and they may not be a good indicator of recharge-elevation for springs because of their year-to-year and seasonal variability. The snow sample at $2652 \mathrm{~m}$ is displaced $9 \%$ in deuterium from the local meteoric water line based on its oxygen-18 content, but its low value compared to the isotope elevation line may indicate that the line has a much more negative slope above some elevation.

Some of the springs are significantly lighter in isotopic composition compared to the isotope-elevation line, indicating that the water fell as precipitation and probably recharged the ground-water system at higher elevations. Crystal and Parkdale springs both have isotope values significantly lighter than the isotope-elevation line, and their indicated recharge elevations are approximately $1600 \mathrm{~m}$ and $1400 \mathrm{~m}$. The Robin Hood Quarry Spring sampled by Wollenberg and others (1979) may also have high-elevation recharge, but it drains the mountains east of Mount Hood and could have a somewhat different 
isotope-elevation line. Swim Warm Springs has a range of isotopes from the mixing of warm and nonthermal water (see discussion below), and the lightest isotopes are consistent with high elevation recharge. The Meadows springs contain a component of thermal water, and the values are somewhat lighter than the isotope-elevation line but not by a large amount. One of Wollenberg and others (1979) samples was collected from one of the Meadows springs and plots close to them. The spring near the Cascade has very similar isotopes to the Meadows Springs but is at a much lower elevation. It will be shown below that the spring near the Cascade is chemically very similar to the Meadows springs.

The Palmer Spring at $1865 \mathrm{~m}$ elevation is on the isotope-elevation line, indicating relatively local recharge. Although the Salmon River sampled in 1999 at the same elevation had much higher sodium and chloride concentrations, concentrations vary throughout the year depending on the schedule of salt application (Mt. Hood National Forest, 1999, 2000, 2001). The lighter isotopes of the Salmon River water compared to the Palmer Spring indicate that the spring is not immediately connected to the surface-water system. The Phlox Point and Still Creek springs that contain smaller amounts of dissolved sodium chloride have slightly heavier isotopes than Palmer Spring indicating that some of the recharge may be from a lower elevation where no salt is applied. The Salmon River isotope values are significantly lighter than all of the springs, but the water is recent snow melt and may not be representative of water that recharges the ground water over the long-term. If it is representative, the snow melt in the Salmon River on that day was dominated by higher elevation melting.

\section{Swim Warm Springs}

Swim Warm Springs is a complex of vents informally named after a ruined swimming pool. The variation of specific conductance with temperature (Figure 12) indicates varying degrees of mixing between a warm water and a nonthermal water. The Schoeller diagram presentation (with a log scale) in Figure 13 has data selected to minimize what appear to be analytical rather than sample differences and shows that the more concentrated samples are a mixture of a concentrated water with a dilute water that contains significant silica and nearly negligible amounts of other constituents. The two dilute samples have a more complex behavior indicating either that there is a somewhat different concentrated water before dilution or additional reaction after dilution. The concentration of magnesium increases along with all other constituents (Figures 13 and 14), indicating that the hot end member has a high concentration of magnesium. All the data are plotted in Figure 14, and some of the scatter is from analytical uncertainty that is removed in the selected data set of Figure 13. But the displacement of the two low-chloride data points (49.5 and $25 \mathrm{mg} / \mathrm{L}$ ) from the mixing line (Figure 14) appears to be a real difference based on the overall behavior in Figure 13.

Isotopic data show that the Swim Warm Springs samples lie along the local meteoric water line (Figure 9). The mixed nature of the samples from Swim Warm Springs is confirmed by plots of isotopes versus chloride (Figure 15). The recharge elevation for the isotopically lightest sample from Swim Warm Springs is approximately $2400 \mathrm{~m}$ based on plots of deuterium and oxygen-18 versus elevation (Figures 10 and 11). Interpretation of chemical geothermometer values (Tables 2 and 3 ) is somewhat difficult. The chalcedony geothermometer temperature for the most concentrated samples from the East Swimming Pool is about $100^{\circ} \mathrm{C}$, the calculated $\mathrm{Na}-\mathrm{K}-\mathrm{Ca}$ temperature is about $80^{\circ} \mathrm{C}$, and the sulfate- 
oxygen isotope temperature for this spring is $110^{\circ} \mathrm{C}$ (Nehring and others, 1979). However, the $\mathrm{Mg}$-corrected $\mathrm{Na}-\mathrm{K}-\mathrm{Ca}$ geothermometer and $\mathrm{Mg}$-Li geothermometers agree at about $30^{\circ} \mathrm{C}$. The concordance of the $\mathrm{Mg}$-corrected $\mathrm{Na}-\mathrm{K}-\mathrm{Ca}$ and $\mathrm{Mg}-\mathrm{Li}$ geothermometers indicates that the warm end member for Swim Warm Springs was at about $30^{\circ} \mathrm{C}$; the most concentrated sample seems to approximate this warm end member. A hot end-member water at $100^{\circ} \mathrm{C}$ could exist at some distance from Swim, as indicated by the sulfate-oxygen temperature. This water could lose energy by conductive heat loss, re-equilibrate to around $30^{\circ} \mathrm{C}$, and then become the warm end member for mixed waters at Swim. Although the loss of $70^{\circ} \mathrm{C}$ by conductive heat transfer is possible, it is pretty large.

An alternative interpretation for the data from Swim Warm Springs starts with the silica versus temperature plot shown in Figure 16. The silica versus temperature mixing line can be converted to silica versus enthalpy plot, the intersection of this mixing line with chalcedony or quartz solubility curves would show that there is a parent hot water at some high values of silica and enthalpy (Truesdell and Fournier, 1977). However, the extension of the silica-enthalpy mixing line does not intersect the solubility curves, and thus the warmsprings mixing model does not apply. Another model assumes that a parent hot-water exists at surface boiling (taken as $96^{\circ} \mathrm{C}$ at the elevation of Swim) that mixes with nonthermal water to obtain the range of mixed compositions shown. This parent hot-water is assumed to boil from the reservoir temperature to surface boiling (Truesdell and Fournier, 1977). Applying this model to the silica-enthalpy mixing line, a reservoir temperatures of $187^{\circ} \mathrm{C}$ for quartz saturation is obtained. Wollenberg and others (1979) give temperatures of 192$240^{\circ} \mathrm{C}$ for a similar calculation with somewhat different assumptions. The deuterium and oxygen-18 isotopes in the reservoir fluid calculated using procedures in Truesdell and others (1977) are $-134.3 \%$ and $-17.6 \%$. These values are quite light compared to the projections of the isotope-elevation lines in Figures 10 and 11. It is possible that the isotope-elevation lines change slope at some elevation higher than that sampled by the springs as suggested by the very light values for the snow sample at $2652 \mathrm{~m}$. Also the mixing lines in Figure 15 used to extrapolate to the values in boiled water have slopes that are not well defined. So the very light values of the isotopes calculated for the reservoir may be only approximately correct. In order to explain the high magnesium in the samples from Swim Warm Springs, this model assumes that there was additional chemical reaction after boiling to add magnesium and possibly sulfate.

The discharge of thermal energy from Swim Warm Springs can be calculated a number of ways. The flow and specific conductance of the two streams draining Swim were measured (Table 1). We will use the data from 2001 as the flows were measured more carefully than in 1997. Using the relation between specific conductance and temperature in Figure 12, the measured specific conductance of the streams can be converted to a temperature. Based on the correlation in Figure 12, we use a reference temperature of $7.1^{\circ} \mathrm{C}$, and the discharge of thermal energy above that is $0.9 \mathrm{MW}_{\mathrm{t}}$. Based on a plot of specific conductance versus chloride (not shown), the measured specific conductance can be used to calculate a chloride flux of $1800 \mathrm{mg} / \mathrm{s}$. From the reservoir chloride of $544 \mathrm{mg} / \mathrm{L}$, calculated from a chloride versus enthalpy plot, and the reservoir enthalpy of $775 \mathrm{j} / \mathrm{g}$ above a $5^{\circ} \mathrm{C}$ reference temperature (based on an estimate of nonthermal water temperature from Figure 3 at Swim's elevation), discharge of thermal energy is $2.2 \mathrm{MW}_{\mathrm{t}}$. Mariner and others (1990) measured a thermal-water flow of $6.4 \mathrm{~L} / \mathrm{s}$ based on a chloride balance on Still Creek. At the spring temperature of $26^{\circ} \mathrm{C}$, their flow yields a discharge of thermal energy of 0.6 $\mathrm{MW}_{\mathrm{t}}$ adjusted to $5^{\circ} \mathrm{C}$ reference temperature; using the aquifer temperature of $110^{\circ} \mathrm{C}$, the 
heat discharge is $2.8 \mathrm{MW}_{\mathrm{t}}$. The aquifer convective heat flow from Swim Warm Springs is not particularly large for thermal springs in the Cascades (Mariner and others, 1990).

\section{Meadows Springs}

The Meadows Springs are a complex of vents informally named after the Meadows ski area in which they occur. The Schoeller diagram presentation (with a log scale) in Figure 17 shows that the more concentrated samples from the Meadows Spring are mixture of a concentrated water with a dilute water that contains significant silica and nearly negligible amounts of other constituents. The two dilute samples from the East Meadows Spring have a more complex pattern indicating either that there is a somewhat different concentrated water before dilution or additional reaction after dilution. The data for the spring tributary to the Zigzag River are shown for reference as a nonthermal water. The chemistry of the Meadows Spring appears to be significantly different in relative proportions from Swim Warm Springs (compare Figures 13 and 17). The sample from the spring near the Cascade is $6 \mathrm{~km}$ from the Meadows (Figure 5) and has very similar (but not identical) chemistry to the Meadows Spring (Figure 17). The appearance of this water at such a distance and at a much lower elevation indicates that this system may be fairly widespread. The concentration of magnesium increases along with all other constituents (Figures 17 and 14), indicating that the hot end member has a high concentration of magnesium. The three samples from the Meadows Spring collected in three different years have temperatures of $4.8,6.1$, and $6.6^{\circ} \mathrm{C}$, and the chemistry reflects these increases with increasing concentrations of each constituent (Table 3 and Figure 17). The temperature of $10.5^{\circ} \mathrm{C}$ measured in a seep below the Meadows Spring (Table $1 ; \mathrm{C} 01-05$ ) is thought to have been influenced by solar heating and is assumed to not be representative. The Meadows Spring fits the definition of a slightly thermal spring but not that of a thermal spring. Calculated geothermometer temperatures range from $40^{\circ}-70^{\circ} \mathrm{C}$ (Table 3$)$, but they are much above the measured spring temperatures.

As with the data for Swim Warm Springs, an alternative but speculative interpretation for the data from Meadows Spring starts with the silica versus temperature plot shown in Figure 18. The three samples for Meadows Spring form a mixing line consistent with a nonthermal water for this elevation of around $2.5^{\circ} \mathrm{C}$ and $21 \mathrm{mg} / \mathrm{L}$ silica. Surprisingly, the sample from the spring near the Cascade lies on the same silica mixing line as that for the Meadows Spring (Figure 18), although the data for specific conductance versus temperature define a parallel trend (Figure 4). The samples from the East Meadows Spring has higher silica than is consistent with this model, and their chemistry, as already indicated by the data in Figure 17, is more complex. Given the limited range in silica concentrations and temperatures for the three samples from the Meadows Spring, the mixing line defined by them is pretty spectacular. The projection of the mixing line does not intersect either the chalcedony or quartz saturation curves, and the estimate of reservoir temperature once again assumes that a parent hot-water exists at surface boiling (taken as $94^{\circ} \mathrm{C}$ at the elevation of the Meadows) that mixes with nonthermal water to obtain the range of mixed compositions shown. This parent hot-water is assumed to boil from the reservoir temperature to surface boiling (Truesdell and Fournier, 1977). Applying this model to the silica-enthalpy mixing line, a reservoir temperatures of $233^{\circ} \mathrm{C}$ for quartz saturation is obtained. The reservoir chloride is calculated to be $563 \mathrm{mg} / \mathrm{L}$, quite similar to the value of $544 \mathrm{mg} / \mathrm{L}$ found for Swim Warm Springs with a similar model. The isotopic data are 
consistent with both the warm and nonthermal mixing components having the same isotopic values (Figure 15), but the range of chloride concentrations is so small that there could be a nonzero slope that we would not recognize. The estimated elevation for the precipitation is 2700-2900 m based on the isotope-elevation plots (Figures 10 and 11). Thus the Meadows system recharges at a lower elevation than Swim and discharges at a higher elevation about $7 \mathrm{~km}$ northeast of Swim, and they appear to be two separate hydrothermal systems.

The discharge of thermal energy can be calculated using the conductance versus temperature relation for the three samples from the Meadows spring. The samples from the East Meadows Spring are a bit off the line for an assumed nonthermal water of $2.5^{\circ} \mathrm{C}$ and specific conductance of $40 \mu \mathrm{S} / \mathrm{cm}$. From the measurement of total flow and specific conductance of the Meadows springs in 2001 (Table 1), the discharge of thermal energy is $0.3 \mathrm{MW}_{\mathrm{t}}$ above a $2.5^{\circ} \mathrm{C}$ reference temperature (based on an estimate of nonthermal water temperature from Figure 3 at the Meadows' elevation). Assuming that the Cascade springs are part of the same system, another $0.6 \mathrm{MW}_{\mathrm{t}}$ is added. Based on a plot of specific conductance versus chloride (not shown), the measured specific conductance can be used to calculate a chloride flux for both the Meadows and Cascade springs of $1300 \mathrm{mg} / \mathrm{s}$. From the reservoir chloride of $563 \mathrm{mg} / \mathrm{L}$, calculated from a chloride versus enthalpy plot, and the reservoir enthalpy of $994 \mathrm{j} / \mathrm{g}$ above a $2.5^{\circ} \mathrm{C}$ reference temperature, discharge of thermal energy is $1.9 \mathrm{MW}_{\mathrm{t}}$. Thus, the discharge of thermal energy from the Meadows springs and Cascade springs is approximately the same as from Swim Warm Springs.

\section{Well Samples}

Water chemistry data from a number of drill hole samples are available in the literature, and some have been included in Table 2. Old Maid Flat well samples (Wollenberg and others, 1979) have not been included because their low silica values probably indicate contamination with drill water. Additional data from Priest and Vogt (1982) for samples from Old Maid Flat-7A drill hole also have not been included, because they also have low silica values, indicating contamination with drill water (Priest and others, 1982, p. 16). Figure 19 presents data from the well samples from Table 2 along with data for Swim Warm Springs and the Meadows spring. The data for the Pucci drill hole are from a sample collected on 7/24/81 during the pump test completed on 7/25/81 (U.S. Geological Survey Press Release, August 13, 1981) after the well had been deepened to $1220 \mathrm{~m}$. The chemistry of the sample from the Pucci well is somewhat similar to that for Swim Warm Springs, with sulfate and chloride nearly equal and both greater than bicarbonate. The cations are less similar. The chloride concentration of the Pucci sample is about twice that of the most concentrated sample from Swim Warm Springs, but its silica concentration is only $5 \%$ higher (Tables 2 and 3). The Pucci well sample is shifted from the local meteoric water line (Figure 9) -- surprising considering that maximum temperature in the well is $77^{\circ} \mathrm{C}$ (Nathenson and Tilling, 1993). From its position on the deuterium versus chloride plot (Figure 15), the sample from the Pucci well could be interpreted as a parent water for Swim Warm Springs. However, the strong relationship between increasing chloride and increasing magnesium for the various samples from Swim Warm Springs (Figure 14) requires the local parent water for Swim Warm Springs to have significantly higher magnesium concentration than that for the Pucci well. The substantially lower chloride concentration and higher magnesium concentration of the East Swimming Pool sample compared to the Pucci sample indicates that the Pucci water is not likely to be the 
parent water for Swim Warm Springs. The sample from the Pucci Well contains a significant amount of magnesium, and the $\mathrm{Mg}$-correction to the $\mathrm{Na}-\mathrm{K}-\mathrm{Ca}$ geothermometer lowers the temperature from $170^{\circ}$ to $52^{\circ} \mathrm{C}$ (Table 2). Measured temperature at a depth of $1129 \mathrm{~m}$ is $76.6^{\circ} \mathrm{C}$, and the maximum temperature is probably somewhat higher as the well is $1220 \mathrm{~m}$ deep. The $\mathrm{K}-\mathrm{Mg}$ geothermometer temperature of $75^{\circ} \mathrm{C}$ agrees well with the measured temperature; however, the high $\mathrm{Na}-\mathrm{K}-\mathrm{Ca}$ temperature of $170^{\circ} \mathrm{C}$ may indicate that a higher temperature water is circulating at greater depths and re-equilibrating at a shallower level. The shift of the oxygen-18 isotopes from the meteoric water line (Figure 9) indicates high temperature but should be regarded with caution as it is based on only a single sample.

In addition to surface thermal features, two shallow wells show influence of subsurface thermal water. The samples from the Parkdale well and the Clear Creek Picnic area well have chloride concentrations enough above background to indicate that they are probably thermal waters or they are mixed with a thermal component (Table 2). No obvious relationship exists (Figure 19) between the waters from the Parkdale and Clear Creek Picnic area wells and the East Swimming Pool of Swim Warm Springs and the Pucci drill hole. They all appear to have undergone slightly different water/rock interactions.

The Parkdale drill hole (Figure 5), located east of the Parkdale Spring is close to the Hood River fault zone, has a maximum measured temperature of $24^{\circ} \mathrm{C}$ at $50 \mathrm{~m}$, and the reversal in the temperature profile clearly indicates movement of thermal water (Steele and others, 1982, Figure 6). The Parkdale well sample is dominantly a sodium bicarbonate water, whereas the other three waters shown on Figure 19 share the atypical characteristic for thermal waters of being relatively high in magnesium concentration. Geothermometer values for the Parkdale well are concordant at a reservoir temperature of $95^{\circ} \mathrm{C}$. The sample has a significant $\mathrm{Mg}$-correction to the $\mathrm{Na}-\mathrm{K}-\mathrm{Ca}$ geothermometer, allowing one to speculate about possibly higher temperatures at depth. The Parkdale well is clearly part of a hydrothermal system, in which the water sampled has undergone significant conductive heat loss to cool it from a geothermometer temperature of $95^{\circ} \mathrm{C}$ to a measured temperature of $24^{\circ} \mathrm{C}$. The lack of any appearance of similar chemistry in the Parkdale cold spring, the lack of specific-conductance anomalies in other springs in the Hood River Valley west of the Parkdale drill hole, and the location of the drill hole adjacent to the Hood River fault makes it likely that the chemical and thermal anomaly is related to faulting rather than thermal affects from hydrothermal systems associated with Mount Hood.

The Clear Creek Picnic area well near the Sandy River at the eastern end of Old Maid Flat (Figure 5) is slightly artesian (Wollenberg and others, 1979), but it has a nearly linear thermal gradient of $56^{\circ} \mathrm{C} / \mathrm{km}$ to $90 \mathrm{~m}$ and does not appear to be thermally anomalous (Steele and others, 1982, Figure 2). Geothermometer values for the Clear Creek Picnic area well are concordant at a reservoir temperature of $70^{\circ} \mathrm{C}$. The sample has a $47^{\circ} \mathrm{C} \mathrm{Mg}$ corrections to the Na-K-Ca geothermometer, but the general indications seem to be consistent with a reservoir temperature around $70^{\circ} \mathrm{C}$. The great distance of the well from the Mount Hood edifice and from other indications of thermal water with sources on Mount Hood make it likely that it is some locally driven system rather than connected to hydrothermal systems associated with Mount Hood. 


\section{Summit Fumaroles}

Mount Hood has several fumaroles (Devils Kitchen and other localities) near the summit (Friedman and others, 1982). The near-summit fumaroles occur at elevations of 3020-3230 m encompassing a surface area of 9200 to $9700 \mathrm{~m}^{2}$ (Friedman and others, 1982; Nehring and others, 1981). Temperatures of summit fumaroles range from $71^{\circ}$ to $93^{\circ} \mathrm{C}$; boiling temperature at $3100 \mathrm{~m}$ elevation is about $89.6^{\circ} \mathrm{C}$. Friedman and others (1982) estimate a total heat discharge for the summit fumarole field of about $10 \mathrm{MW}_{\mathrm{t}}$, comparable to the fluxes for Mount Rainier of 9.6 MW $\mathrm{M}$ and Mount Baker in 1972 of 12 $\mathrm{MW}_{\mathrm{t}}$ (before the increase in thermal activity in 1975 to $82 \mathrm{MW}_{\mathrm{t}}$ [Frank, 1985]). Table 4 presents gas analyses for the summit fumaroles and the D'Amore and Panichi (1980) gas geothermometer to estimate reservoir temperatures. Gas samples are sometimes contaminated with entrained air, and the 1978 sample from the ridge west of Devils Kitchen has nitrogen, oxygen, and argon in the appropriate ratios for air. The carbon dioxide content in this sample is much higher than that for air, but the application of the geothermometer to such a heavily contaminated sample is inappropriate. The 1935 and 1951 samples of Crater Rock also have high oxygen contents and are inappropriate for application of the geothermometer. The 1935 sample from Devils Kitchen lacks data for methane and hydrogen, and a geothermometer temperature has not been calculated for it. Samples with higher amounts of nitrogen tend to have lower amounts of hydrogen sulfide, because the added nitrogen was from air added either in the near surface part of the vent or in sampling, and the associated oxygen reacts with hydrogen sulfide to form sulfur and water until either the oxygen or hydrogen sulfide is gone (Nehring and others, 1981). Geothermometer temperatures for the Base of Steel Cliff are around $290^{\circ} \mathrm{C}$ for the modern analysis, for Devils Kitchen are around $325^{\circ} \mathrm{C}$, and for Crater Rock are the highest at $360^{\circ} \mathrm{C}$. These high temperatures are somewhat surprising because the last significant eruption from Mount Hood was about 200 years ago. The calculated reservoir temperatures for Swim Warm Springs and the Meadows Spring are quite a bit lower than the temperatures calculated for the fumaroles indicating that the fumaroles are not just the vents for the boiling hydrothermal systems.

A sample from a summit fumarole collected in 1978 has a ${ }^{3} \mathrm{He} /{ }^{4} \mathrm{He}$ ratio of 7.2 times that for air (Welhan and others, 1988; Poreda and Craig, 1989), one collected in 1997 had a value of 7.6 (Symonds and others, 2003), and samples collected in August, 2002 had values of 6.35 and 6.68 times that for air (M. C. van Soest, analyst). These values are similar to those found in other Cascade volcanoes and about what would be expected for degassing of andesitic magma that has a source in the mantle. Thus, the summit fumaroles involve input of magmatic volatiles that have been modified by scrubbing (Symonds and others, 2003). Whether the difference in helium-ratio values over time is significant is unclear.

\section{Conclusions}

Temperatures of nonthermal springs on Mount Hood decrease with elevation and are similar to air temperatures from nearby weather stations. Dissolved constituents in nonthermal springs generally increase with spring temperature and reflect weathering of volcanic rock from the action of dissolved carbon dioxide. Salt that is applied to the Palmer 
snow field is found in several nonthermal springs. Isotopic contents of nonthermal springs follow a local meteoric water line and generally decrease in deuterium and oxygen-18 with elevation. Some nonthermal springs at low-elevation have light values of isotopes indicating a high-elevation source for the water.

Three hydrothermal systems have been identified on Mount Hood. Swim Warm Springs is a complex of springs with temperatures ranging to $26^{\circ} \mathrm{C}$. Chemistry and isotopic variations generally reflect mixing a warm water with a dilute water that contains significant silica. Magnesium content increases with chloride and temperature indicating that the warm end member must have undergone some low-temperature reaction as magnesium is normally very low in thermal water. One model for Swim Warm Springs is that the hot end member is $110^{\circ} \mathrm{C}$ and has undergone significant conductive heat loss to reduce its temperature to the $25^{\circ} \mathrm{C}$ vent temperature. A second model involves boiling of a reservoir water from $187^{\circ} \mathrm{C}$ to the local boiling temperature of $96^{\circ} \mathrm{C}$. Additional low-temperature equilibration added magnesium and subsequent mixing with nonthermal water produced the range of compositions found in the various vents. Isotopic contents calculated for the $187^{\circ} \mathrm{C}$ reservoir water are very light compared to the extrapolation of the isotope elevation line, but the extrapolation is somewhat uncertain, and there is an indication that the slope of the isotope-elevation line may become more negative at higher elevations.

The Meadows Spring only ranges in temperature to $6.6^{\circ} \mathrm{C}$. Similar to Swim, a model involving boiling, $223^{\circ} \mathrm{C}$ in this case, and subsequent low-temperature equilibration with added magnesium and subsequent mixing with nonthermal water produce the range of compositions found. The mixing line for isotopes versus chloride is poorly constrained in this case because of the limited range of chloride contents, and the available data are consistent with the isotopes being constant with increasing chloride concentration. The elevation for the projected isotopic contents is $2700-2900 \mathrm{~m}$, lower than the summit elevation of $3426 \mathrm{~m}$.

The fumaroles near the summit have somewhat variable compositions between the various vents. The older analyses should be regarded with some caution, but the vent at the base of Steel Cliff does seem to have a lower hydrogen content than the other vents. The calculated temperatures for this vent may not be reliable, because the analyses are so old. The other vents discharge gases that consistently indicate system temperatures over $300^{\circ} \mathrm{C}$, providing an ample fluid and heat source to develop hydrothermal systems. The calculated reservoir temperatures for Swim Warm Springs and the Meadows Spring are lower than the temperatures calculated for the fumaroles indicating that the fumaroles are not just the vents for the boiling hydrothermal systems.

Representative values for the various measurements of thermal discharge for the three hydrothermal systems are $10 \mathrm{MW}_{\mathrm{t}}$ for the fumaroles, $2.2 \mathrm{MW}_{\mathrm{t}}$ for Swim, and 1.9 $\mathrm{MW}_{\mathrm{t}}$ for the Meadows and Cascade Springs. There are quite possibly more areas of discharge of slightly thermal water that could add to the totals for the springs, but the amounts of heat discharge are not very large. Based on a comparison of heat flows measured in drill holes to a model for heat loss from an isothermal magma chamber, Nathenson and Tilling (1993) estimated that the conductive heat loss from Mount Hood is between 28 and $55 \mathrm{MW}_{\mathrm{t}}$. This conductive heat loss is larger than the total of all convective heat discharges found at the surface. The small magnitudes of the convective heat discharge for Swim and the Meadows springs are surprising given the high temperatures estimated for the source water and may indicate that these systems are not large in volume. This supposition is consistent with conductive heat flows found in the deep (>300 m) drillholes at Mount Hood (Steele and others, 1982; Nathenson and Tilling, 1993). 


\section{Acknowledgments}

Robert Mariner and Cathy Janik are thanked for helpful reviews that improved the clarity of the paper. Isotopic data in Table 2 and some of the gas analyses in Table 4 provided from USGS files by Cathy Janik. Dale Counce of Los Alamos National Laboratory provided the chemical analyses in Table 3. Judy Windt provided helpful field assistance. Work supported by the U.S. Geological Survey Volcano Hazards Program.

\section{References}

Ayers, F. D., and Creswell, A. E., 1951, The Mount Hood Fumaroles: Mazama, v. 33, n. 13, p. 3340.

Bliss, J. D., 1983, Oregon Basic data for thermal springs and wells as recorded in GEOTHERM: U.S. Geological Survey Open-File Report 83-435, 247 p.

Cameron, K. A., and Pringle, P. T., 1986, Post-glacial lahars of the Sandy River basin, Mount Hood, Oregon: Northwest Science, v. 60, p. 225-237.

Cameron, K. A., and Pringle, P. T., 1987, A detailed chronology of the most recent major eruptive period at Mount Hood, Oregon: Geological Society of America Bulletin, v.99, p. 845-851.

Crandell, D. R., 1980, Recent eruptive history of Mount Hood, Oregon, and potential hazards from future eruptions: U.S. Geological Survey Bulletin 1492, 81 p.

D'Amore, Franco, and Panichi, Costanzo, 1980, Evaluation of deep temperatures of hydrothermal systems by a new gas geothermometer: Geochimica et Cosmochimica Acta, v. 44, p.549-556.

Dansgaard, W., 1964, Stable isotopes in precipitation: Tellus, v. 16, p. 436-468.

Fournier, R. O., 1981, Application of water geochemistry to geothermal exploration and reservoir engineering, in Rybach, L., and Muffler, L. J. P., eds., Geothermal Systems: Principles and Case Histories, John Wiley, p. 109-143.

Frank, D. G., 1985, Hydrothermal processes from Mount Rainier, Washington: PhD Dissertation, University of Washington, $196 \mathrm{p}$.

Friedman, J. D., Williams, D. L., and Frank, David, 1982, Structural and heat flow implications of infrared anomalies at Mt. Hood, Oregon, 1972-1977: Journal of Geophysical Research, v.87, p. 2793-2803.

Giggenbach, W. F., 1986, Graphical techniques for the evaluation of water/rock equilibration conditions by use of $\mathrm{Na}, \mathrm{K}, \mathrm{Mg}$, and Ca-contents of discharge waters: Proceedings of the 8th New Zealand Geothermal Workshop, University of Auckland Geothermal Institute, p.37-43.

Gonfiantini, R., 1978, Standards for stable isotope measurements in natural compounds: Nature, v. 271 , p. $534-536$.

Ingebritsen, S. E., Sherrod, D. R., and Mariner, R. H., 1992, Rates and patterns of groundwater flow in the Cascade Range volcanic arc, and the effect on subsurface flow: Journal of Geophysical Research, v. 97, p. 4599-4627.

Kharaka, Y. K., and Mariner, R. H., 1989, Chemical geothermometers and their application to formation waters from sedimentary basins, in Naeser, N. D., and McCulloh, T. H., eds., Thermal History of Sedimentary Basins: Springer-Verlag, New York, p. 99-117.

Mariner, R. H., Evans, W. C., Presser, T. S., and White, L. D., 2003, Excess nitrogen in selected thermal and mineral springs of the Cascade Range in northern California, Oregon, and Washington: sedimentary or volcanic in origin?: Journal of Volcanology and Geothermal Research, v. 121, p. 99-114. 
Mariner, R. H., Presser, T. S., Evans, W. C., and Pringle, M. K. W., 1990, Discharge rates of fluid and heat by thermal springs of the Cascade Range, Washington, Oregon, and northern California: Journal of Geophysical Research, v. 95, p.19,517-19,531.

McKenzie, W. F., and Truesdell, A. H., 1977, Geothermal reservoir temperatures estimated from the oxygen isotope compositions of dissolved sulfate and water from hot springs and shallow drillholes: Geothermics, v. 5, p. 51-61.

Meinzer, O. E., 1923. Outline of ground-water hydrology with definitions: U.S. Geological Survey Water-Supply Paper 494, $71 \mathrm{p}$.

Mt. Hood National Forest, 1999, Land and Resource Management Plan, Monitoring Report, Fiscal Year 1998, U.S. Forest Service, 166 p.

Mt. Hood National Forest, 2000, Land and Resource Management Plan, Monitoring Report, Fiscal Year 1999, U.S. Forest Service, 176 p.

Mt. Hood National Forest, 2001, Land and Resource Management Plan, Monitoring Report, Fiscal Year 2000, U.S. Forest Service, 166 p.

National Oceanic and Atmospheric Administration, 1997a, Climatological data annual summary Oregon 1997, v. 103, n. 13, National Climatic Data Center, Asheville, N.C., 32 p.

National Oceanic and Atmospheric Administration, 1997b, Climatological data annual summary Washington 1997, v. 101, n. 13, National Climatic Data Center, Asheville, N.C., 25 p.

Nathenson, Manuel, 1990, Temperatures of springs in the vicinity of Crater Lake, Oregon, in relation to air and ground temperatures: U.S. Geological Survey Open-File Report 90$671,19 p$.

Nathenson, Manuel, and Thompson, J. M., 1990, Chemistry of Crater Lake, Oregon, and nearby springs in relation to weathering, in Drake, E. T., Larson, G. L., Dymond, J., and Collier, R., eds., Crater Lake, An Ecosystem Study, Pacific Division, American Association for the Advancement of Science, San Francisco, p. 115-126.

Nathenson, M., Thompson, J. M., and White, L. D., 2003, Slightly thermal springs and nonthermal springs at Mount Shasta, California: Chemistry and recharge elevations: Journal of Volcanology and Geothermal Research, v. 121, p. 137-153.

Nathenson, M., and Tilling, R. I., 1993, Conductive heat transfer from an isothermal magma chamber and its application to the measured heat flow distribution from Mount Hood, Oregon: Geothermal Resources Council Transactions, v. 17, p. 141-148.

Nehring, N. L., Mariner, R. H., White, L. D., Huebner, M. A., Roberts, E. D., Harmon, Karen, Bowen, P. A., and Tanner, Lane, 1979, Sulfate geothermometry of thermal waters in the Western United States: U.S. Geological Survey Open-File Report 79-1135, 11 p.

Nehring, N. L., Wollenberg, H. A., and Johnston, D. A., 1981, Gas analyses of fumaroles from Mt. Hood, Oregon: U.S. Geological Survey Open-File Report 81-236, 9 p.

Phillips, K. N., 1936, A chemical study of the fumaroles of Mount Hood: Mazama, v. 18, n. 12, p. 44-46.

Poreda, R., and Craig, H., 1989, Helium isotope ratios in circum-Pacific volcanic arcs: Nature, v.338, p. $473-478$.

Priest, G. R., Beeson, M. H., Gannett, M. W., Berri, D. A., 1982, Geology, geochemistry, and geothermal resources of the Old Maid Flat area, Oregon, in Priest, G. R., and Vogt, B. F., eds., Geology and Geothermal Resources of the Mount Hood area, Oregon: Special Paper 14, Oregon Department of Geology and Mineral Industries, p. 16-30.

Priest, G. R., and Vogt, B. F., eds., 1982, Geology and geothermal resources of the Mount Hood Area, Oregon: Special Paper 14, Oregon Department of Geology and Mineral Industries, $100 \mathrm{p}$.

Reed, M. J., 1983, Introduction, in Reed, M. J., ed., Assessment of low-temperature geothermal resources of the United States - 1982: U.S. Geological Survey Circular 892, p. 1-8.

Rose, T. P., Davisson, M. L., and Criss, R. E., 1996, Isotope hydrology of voluminous cold springs in fractured rock from an active volcanic region, northeastern California: Journal of Hydrology, v. 179, p. 207-236.

Scott, W. E., Gardner, C. A., Sherrod, D. R., Tilling, R. I., Lanphere, M. A., and Conrey, R. M., 1997, Geologic history of Mount Hood Volcano, Oregon-A field-trip guidebook: U.S. Geological Survey Open-File Report 97-263, 38 p. 
Steele, J. L., Blackwell, D. D., and Robison, J. H., 1982, Heat flow in the vicinity of the Mount Hood volcano, Oregon, in Priest, G. R., and Vogt, B. F., eds., Geology and Geothermal Resources of the Mount Hood area, Oregon: Oregon Department of Geology and Mineral Industries Special Paper 14, p. 31-42.

Symonds, R. B., Janik, C. J., Evans, W. C., Ritchie, B. E., Counce, Dale, Poreda, R. J., and Iven, Mark, 2003, Scrubbing masks magmatic degassing during repose at Cascade-Range and Aleutian-Arc volcanoes: U.S. Geological Survey Open-File Report 03-435, 22 p., available at http://geopubs.wr.usgs.gov/open-file/of03-435/

Truesdell, A. H., and Fournier, R. O., 1977, Procedure for estimating the temperature of a hotwater component in a mixed water by using a plot of dissolved silica versus enthalpy: U.S. Geological Survey Journal of Research, v. 5, p. 49-52.

Truesdell, A. H., Nathenson, Manuel, and Rye, R. O., 1977, The effects of subsurface boiling and dilution on the isotopic compositions of Yellowstone thermal waters: Journal of Geophysical Research, v.82, p.3694-3704.

Waring, G. A., revised by Blankenship, R.R., and Bentall, Ray, 1965. Thermal springs of the United States and other countries of the World -- A summary. U.S. Geological Survey Professional Paper 492, 383 p.

Welhan, J. A., Poreda, R. J., Rison, W., and Craig, H., 1988, Helium isotopes in geothermal and volcanic gases of the Western United States, I. Regional variability and magmatic origin: Journal of Volcanology and Geothermal Research, v. 34, p.185-199.

Wise, W. S., 1969, Geology and petrology of the Mt. Hood area: A study of High Cascade volcanism: Geological Society of America Bulletin, v. 80, p. 969-1006.

Wollenberg, H. A., Bowen, R. E., Bowman, H. R., and Strisower, Beverly, 1979, Geochemical studies of rocks, water, and gases at Mt. Hood, Oregon: Lawrence Berkeley Laboratory Report LBL-7092, $57 \mathrm{p}$. 
Table 1. Mount Hood physical measurements. For one location, measurement point is at feature. For two locations, measurement point is given, and location of feature is also given. Measurements on springs at the orifice are identified by an ${ }^{*}$ after the name.

\begin{tabular}{|c|c|c|c|c|c|c|c|c|c|c|}
\hline & \multirow{2}{*}{$\begin{array}{l}\text { Sample } \\
\text { or ID } \\
\text { No. }\end{array}$} & \multicolumn{2}{|c|}{ Measurement point } & \multirow[b]{2}{*}{$\begin{array}{c}\text { Elev. } \\
\mathrm{m}\end{array}$} & \multirow[b]{2}{*}{ Date } & \multicolumn{2}{|l|}{ Feature } & \multirow[b]{2}{*}{$\begin{array}{l}\text { Flow } \\
\mathrm{L} / \mathrm{s}\end{array}$} & \multirow[b]{2}{*}{$\begin{array}{l}\mathrm{T} \\
{ }^{\circ} \mathrm{C} \\
\end{array}$} & \multirow[b]{2}{*}{$\begin{array}{l}\text { Cond. } \\
\mu \mathrm{S} / \mathrm{cm}\end{array}$} \\
\hline & & Lat. & Lon. & & & Lat. & Lon. & & & \\
\hline \multicolumn{11}{|l|}{ Swim Warm Springs } \\
\hline Below swimming pool & & $45^{\circ} 17.78^{\prime}$ & $121^{\circ} 44.26^{\prime}$ & 1158 & $8 / 1 / 97$ & $45^{\circ} 17.80^{\prime}$ & $121^{\circ} 44.24^{\prime}$ & 6.3 & 16.3 & 655 \\
\hline Still Creek & & $45^{\circ} 17.77^{\prime}$ & $121^{\circ} 44.21^{\prime}$ & 1158 & $8 / 1 / 97$ & & & 19 & 9.2 & 204 \\
\hline Spring nr. Screen Spring* & 2 & $45^{\circ} 17.83^{\prime}$ & $121^{\circ} 44.19^{\prime}$ & 1164 & $8 / 1 / 97$ & & & 0.3 & 22.8 & 939 \\
\hline Spring nr. Screen Spring* & 3 & $45^{\circ} 17.83^{\prime}$ & $121^{\circ} 44.17^{\prime}$ & 1164 & $8 / 1 / 97$ & & & 1.2 & 13.4 & 465 \\
\hline Spring nr. Screen Spring* & 4 & $45^{\circ} 17.82^{\prime}$ & $121^{\circ} 44.17^{\prime}$ & 1164 & $8 / 1 / 97$ & & & 0.3 & 9.0 & 280 \\
\hline Pipeline by swimming pool* & 5 & $45^{\circ} 17.81^{\prime}$ & $121^{\circ} 44.24^{\prime}$ & 1158 & $8 / 1 / 97$ & & & 2 & 17.6 & 576 \\
\hline Sp. nr. Pipeline Sp. * & 6 & $45^{\circ} 17.80^{\prime}$ & $121^{\circ} 44.26^{\prime}$ & 1158 & $8 / 1 / 97$ & & & 0.2 & 21.7 & 1227 \\
\hline E. side of pool* & MNH-97-1 & $45^{\circ} 17.80^{\prime}$ & $121^{\circ} 44.24^{\prime}$ & 1158 & $8 / 1 / 97$ & & & 0.3 & 25.0 & 1263 \\
\hline Sp. nr. Phlox Point* & MNH-97-2 & $45^{\circ} 19.05^{\prime}$ & $121^{\circ} 42.96^{\prime}$ & 1548 & $8 / 2 / 97$ & & & 83 & 2.4 & 45.2 \\
\hline Sp. trib. of Zigzag R.* & MNH-97-3 & $45^{\circ} 20.50^{\prime}$ & $121^{\circ} 44.23^{\prime}$ & 1628 & $8 / 2 / 97$ & & & 26 & 2.3 & 17.5 \\
\hline \multicolumn{11}{|l|}{ Upper Hood River Valley } \\
\hline Crystal Spring* & MNH-97-4 & $45^{\circ} 27.55^{\prime}$ & $121^{\circ} 35.11^{\prime}$ & 744 & $8 / 3 / 97$ & & & 210 & 5.1 & 70.1 \\
\hline Rogers Spring* & & $45^{\circ} 31.14^{\prime}$ & $121^{\circ} 37.20^{\prime}$ & 524 & $8 / 3 / 97$ & & & 57 & 4.8 & 58.1 \\
\hline Spgs. NE1/4 1N10E32 & & $45^{\circ} 32.07^{\prime}$ & $121^{\circ} 35.57^{\prime}$ & 463 & $8 / 3 / 97$ & $45^{\circ} 31.75^{\prime}$ & $121^{\circ} 35.60^{\prime}$ & 19 & 13.9 & 60.4 \\
\hline Parkdale Cold Spring* & MNH-97-5 & $45^{\circ} 29.97^{\prime}$ & $121^{\circ} 36.26^{\prime}$ & 585 & $8 / 3 / 97$ & & & 66 & 7.9 & 102.0 \\
\hline Spgs? NW 1/4 1S9E12 & & $45^{\circ} 30.06^{\prime}$ & $121^{\circ} 36.77^{\prime}$ & 585 & $8 / 3 / 97$ & $45^{\circ} 29.94^{\prime}$ & $121^{\circ} 36.97^{\prime}$ & 5 & 10.2 & 63.0 \\
\hline Spgs. SE 1/2 1S9E01 & & $45^{\circ} 31.18^{\prime}$ & $121^{\circ} 36.45^{\prime}$ & 512 & $8 / 3 / 97$ & $45^{\circ} 30.66^{\prime}$ & $121^{\circ} 36.85^{\prime}$ & 2.4 & 11.7 & 60.3 \\
\hline Sp. on Lolo Pass Rd.* & MNH-97-6 & $45^{\circ} 29.44^{\prime}$ & $121^{\circ} 45.20^{\prime}$ & 695 & $8 / 4 / 97$ & & & 94 & 4.7 & 40.8 \\
\hline Sp. on Coe Branch* & MNH-97-7 & $45^{\circ} 26.70^{\prime}$ & $121^{\circ} 39.41^{\prime}$ & 1000 & $8 / 4 / 97$ & & & 2 & 6.0 & 60.9 \\
\hline \multicolumn{11}{|l|}{ Meadows area } \\
\hline E. Meadows Sp.* & MNH-97-8 & $45^{\circ} 20.34^{\prime}$ & $121^{\circ} 39.91^{\prime}$ & 1792 & $8 / 5 / 97$ & & & 12 & 2.8 & 111.5 \\
\hline Stream from Meadows Spring & & $45^{\circ} 20.31^{\prime}$ & $121^{\circ} 40.05^{\prime}$ & 1743 & $8 / 5 / 97$ & $45^{\circ} 20.37^{\prime}$ & $121^{\circ} 40.05^{\prime}$ & 28 & 5.9 & 246 \\
\hline East Fork Hood River & Cond. 1 & $45^{\circ} 20.24^{\prime}$ & $121^{\circ} 40.25^{\prime}$ & 1768 & $8 / 5 / 97$ & & & 250 & & 10 \\
\hline Stream & Cond. 2 & $45^{\circ} 20.11^{\prime}$ & $121^{\circ} 40.34^{\prime}$ & 1780 & $8 / 5 / 97$ & & & 28 & & 3.4 \\
\hline Stream & Cond. 3 & $45^{\circ} 19.98^{\prime}$ & $121^{\circ} 40.43^{\prime}$ & 1780 & $8 / 5 / 97$ & & & 230 & & 10.1 \\
\hline Mitchell Creek & Cond. 4 & $45^{\circ} 19.92^{\prime}$ & $121^{\circ} 40.51^{\prime}$ & 1768 & $8 / 5 / 97$ & & & 19 & & 10.0 \\
\hline Meadows Spring* & MNH-97-10 & $45^{\circ} 20.37^{\prime}$ & $121^{\circ} 40.05^{\prime}$ & 1798 & $8 / 7 / 97$ & & & 49 & 4.8 & 233 \\
\hline
\end{tabular}


Table 1 (continued).

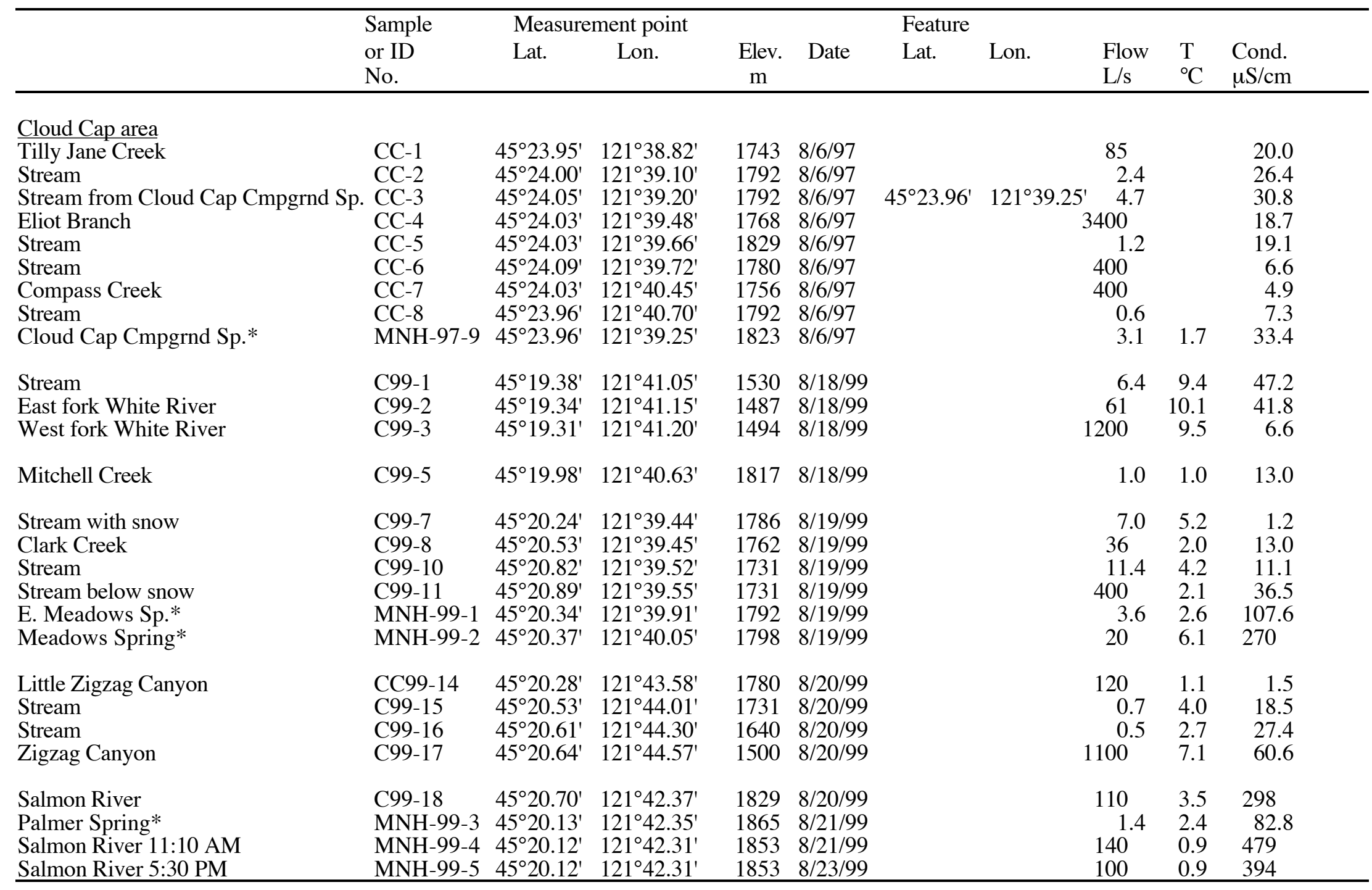


Table 1 (continued).

\begin{tabular}{|c|c|c|c|c|c|c|c|c|c|c|}
\hline & \multirow{2}{*}{$\begin{array}{l}\text { Sample } \\
\text { or ID } \\
\text { No. }\end{array}$} & \multicolumn{2}{|c|}{ Measurement point } & \multirow[b]{2}{*}{$\begin{array}{c}\text { Elev. } \\
\mathrm{m}\end{array}$} & \multirow[b]{2}{*}{ Date } & \multicolumn{2}{|l|}{ Feature } & \multirow[b]{2}{*}{$\begin{array}{l}\text { Flow } \\
\mathrm{L} / \mathrm{s}\end{array}$} & \multirow[b]{2}{*}{$\begin{array}{l}\mathrm{T} \\
{ }^{\circ} \mathrm{C}\end{array}$} & \multirow[b]{2}{*}{$\begin{array}{l}\text { Cond. } \\
\mu \mathrm{S} / \mathrm{cm}\end{array}$} \\
\hline & & Lat. & Lon. & & & Lat. & Lon. & & & \\
\hline Newton Creek & C99-21 & $45^{\circ} 20.21^{\prime}$ & $121^{\circ} 37.54^{\prime}$ & 1414 & $8 / 22 / 99$ & & & 1800 & 5.8 & 14.3 \\
\hline Stream & C99-22 & $45^{\circ} 19.96^{\prime}$ & $121^{\circ} 37.66^{\prime}$ & 1396 & $8 / 22 / 99$ & & & 140 & 4.6 & 19.6 \\
\hline Stream & C99-23 & $45^{\circ} 19.86^{\prime}$ & $121^{\circ} 37.78^{\prime}$ & 1390 & $8 / 22 / 99$ & & & 9.6 & 5.4 & 35.0 \\
\hline Clark Creek & C99-24 & $45^{\circ} 19.77^{\prime}$ & $121^{\circ} 37.84^{\prime}$ & 1390 & $8 / 22 / 99$ & & & 1800 & 7.5 & 41.2 \\
\hline South Fork Iron Creek & C99-25 & $45^{\circ} 18.35^{\prime}$ & $121^{\circ} 40.06^{\prime}$ & 1286 & $8 / 22 / 99$ & & & 54 & 4.4 & 99.3 \\
\hline South Fork Mineral Creek & C99-26 & $45^{\circ} 18.86^{\prime}$ & $121^{\circ} 41.15$ & 1426 & $8 / 22 / 99$ & & & 5.0 & 8.2 & 25.4 \\
\hline Rushing Water Creek & C99-27 & $45^{\circ} 22.51^{\prime}$ & $121^{\circ} 46.72^{\prime}$ & 1030 & $8 / 23 / 99$ & & & 350 & 5.3 & 94.0 \\
\hline Stream & C99-28 & $45^{\circ} 22.54^{\prime}$ & $121^{\circ} 46.70^{\prime}$ & 1024 & $8 / 23 / 99$ & & & 34 & 5.4 & 39.6 \\
\hline Sandy River & C99-29 & $45^{\circ} 22.62^{\prime}$ & $121^{\circ} 46.74^{\prime}$ & 1012 & $8 / 23 / 99$ & & & 1700 & 9.7 & 16.8 \\
\hline Ramona Falls & C99-30 & $45^{\circ} 22.81^{\prime}$ & $121^{\circ} 46.51^{\prime}$ & 1073 & $8 / 23 / 99$ & & & 62 & 10.8 & 22.8 \\
\hline Muddy Fork & C99-31 & $45^{\circ} 23.76^{\prime}$ & $121^{\circ} 47.89^{\prime}$ & 860 & $8 / 23 / 99$ & & & 3600 & 10.6 & 87.0 \\
\hline Middle Fork Cold Springs Creek & $\mathrm{C} 01-01$ & $45^{\circ} 21.80^{\prime}$ & $121^{\circ} 38.47^{\prime}$ & 1817 & $7 / 25 / 01$ & & & 14.4 & 13.3 & 12.8 \\
\hline \multicolumn{11}{|l|}{ Meadows area } \\
\hline Stream from Meadows Spring & $\mathrm{C} 01-02$ & $45^{\circ} 20.31^{\prime}$ & $121^{\circ} 40.05^{\prime}$ & 1743 & $7 / 26 / 01$ & $45^{\circ} 20.37^{\prime}$ & $121^{\circ} 40.05^{\prime}$ & 18 & 7.9 & 354 \\
\hline Stream from E. Meadows Spring & $\mathrm{C} 01-03$ & $45^{\circ} 20.27^{\prime}$ & $121^{\circ} 39.92^{\prime}$ & 1743 & $7 / 26 / 01$ & $45^{\circ} 20.34^{\prime}$ & $121^{\circ} 39.91^{\prime}$ & 4.5 & 3.4 & 157 \\
\hline Meadows Spring* & MNH-01-1 & $45^{\circ} 20.37^{\prime}$ & $121^{\circ} 40.05^{\prime}$ & 1798 & $7 / 26 / 01$ & & & 8.8 & 6.6 & 364 \\
\hline Spring in Meadows* & $\mathrm{C} 01-05$ & $45^{\circ} 20.23^{\prime}$ & $121^{\circ} 40.05^{\prime}$ & 1719 & $7 / 26 / 01$ & & & 0.2 & 10.5 & 270 \\
\hline Main Meadows stream & $\mathrm{C} 01-06$ & $45^{\circ} 20.23^{\prime}$ & $121^{\circ} 40.05^{\prime}$ & 1719 & $7 / 26 / 01$ & & & 16.5 & & 343 \\
\hline Main Meadows stream - lower & $\mathrm{C} 01-07$ & $45^{\circ} 20.16^{\prime}$ & $121^{\circ} 40.01^{\prime}$ & 1695 & $7 / 26 / 01$ & & & 18.0 & & 338 \\
\hline Tilly Jane Creek Spring* & C01-08 & $45^{\circ} 23.67^{\prime}$ & $121^{\circ} 39.38^{\prime}$ & 1890 & $7 / 27 / 01$ & & & 0.3 & 2.6 & 25.2 \\
\hline Stream from snow & C01-09 & $45^{\circ} 23.08^{\prime}$ & $121^{\circ} 39.64^{\prime}$ & 2134 & $7 / 27 / 01$ & & & 2.8 & 4.8 & 1.4 \\
\hline Elk Creek & $\mathrm{C} 01-10$ & $45^{\circ} 25.08^{\prime}$ & $121^{\circ} 46.72^{\prime}$ & 1055 & $7 / 29 / 01$ & & & 10.5 & 8.8 & 21.0 \\
\hline McGee Creek & C01-11 & $45^{\circ} 25.07^{\prime}$ & $121^{\circ} 46.05^{\prime}$ & 908 & $7 / 29 / 01$ & & & 405 & 7.8 & 31.6 \\
\hline McGee Creek tributary & C01-12 & $45^{\circ} 26.00^{\prime}$ & $121^{\circ} 46.35^{\prime}$ & 835 & $7 / 29 / 01$ & & & 68 & 6.4 & 36.5 \\
\hline Ladd Creek & $\mathrm{C} 01-13$ & $45^{\circ} 28.31^{\prime}$ & $121^{\circ} 46.39^{\prime}$ & 701 & $7 / 29 / 01$ & & & 1620 & 6.4 & 25.6 \\
\hline Red Hill Creek & C01-14 & $45^{\circ} 28.33^{\prime}$ & $121^{\circ} 46.17^{\prime}$ & 719 & $7 / 29 / 01$ & & & 54 & 7.4 & 46.0 \\
\hline Clear Branch & C01-15 & $45^{\circ} 27.43^{\prime}$ & $121^{\circ} 40.67^{\prime}$ & 914 & $7 / 29 / 01$ & & & 127 & 7.7 & 55.0 \\
\hline Pinnacle Creek & $\mathrm{C} 01-16$ & $45^{\circ} 27.40^{\prime}$ & $121^{\circ} 39.64^{\prime}$ & 914 & $7 / 29 / 01$ & & & 120 & 7.1 & 49.0 \\
\hline
\end{tabular}


Table 1 (continued).

\begin{tabular}{|c|c|c|c|c|c|c|c|c|c|c|}
\hline & \multirow{2}{*}{$\begin{array}{l}\text { Sample } \\
\text { or ID } \\
\text { No. }\end{array}$} & \multicolumn{2}{|c|}{ Measurement point } & \multirow[b]{2}{*}{$\begin{array}{c}\text { Elev. } \\
\mathrm{m}\end{array}$} & \multirow[b]{2}{*}{ Date } & \multicolumn{2}{|l|}{ Feature } & \multirow[b]{2}{*}{$\begin{array}{l}\text { Flow } \\
\text { L/s }\end{array}$} & \multirow[b]{2}{*}{$\begin{array}{l}\mathrm{T} \\
{ }^{\circ} \mathrm{C}\end{array}$} & \multirow[b]{2}{*}{$\begin{array}{l}\text { Cond. } \\
\mu S / \mathrm{cm}\end{array}$} \\
\hline & & Lat. & Lon. & & & Lat. & Lon. & & & \\
\hline \multicolumn{11}{|l|}{ Swim Warm Springs } \\
\hline Pipeline by swimming pool* & MNH-01-2 & $45^{\circ} 17.81^{\prime}$ & $121^{\circ} 44.24^{\prime}$ & 1158 & $7 / 30 / 01$ & \multirow{6}{*}{$45^{\circ} 17.80^{\prime}$} & \multirow{6}{*}{$121^{\circ} 44.24^{\prime}$} & 0.67 & 15.9 & 575 \\
\hline E. side of pool* & MNH-01-3 & $45^{\circ} 17.80^{\prime}$ & $121^{\circ} 44.24^{\prime}$ & 1158 & $7 / 30 / 01$ & & & 0.05 & 24.7 & 1248 \\
\hline Still Creek & $\mathrm{C} 01-19$ & $45^{\circ} 17.77^{\prime}$ & $121^{\circ} 44.21^{\prime}$ & 1158 & $7 / 30 / 01$ & & & 59 & 9.7 & 231 \\
\hline Below swimming pool & C01-20 & $45^{\circ} 17.78^{\prime}$ & $121^{\circ} 44.26^{\prime}$ & 1158 & $7 / 30 / 01$ & & & 6.3 & 15.6 & 655 \\
\hline Still Creek above Swim & C01-21 & $45^{\circ} 17.87^{\prime}$ & $121^{\circ} 44.17^{\prime}$ & 1167 & $7 / 30 / 01$ & & & & 5.9 & 132 \\
\hline Still Creek @ Hwy 26 & MNH-01-4 & $45^{\circ} 18.05^{\prime}$ & $121^{\circ} 44.10^{\prime}$ & 1195 & $7 / 30 / 01$ & & & 150 & 5.5 & 134.0 \\
\hline Palmer Spring* & MNH-01-5 & $45^{\circ} 20.13^{\prime}$ & $121^{\circ} 42.35^{\prime}$ & 1865 & $7 / 31 / 01$ & & & 0.68 & 2.3 & 69.5 \\
\hline Palmer Spring Box* & $\mathrm{C} 01-24$ & $45^{\circ} 20.18^{\prime}$ & $121^{\circ} 42.32^{\prime}$ & 1884 & $7 / 31 / 01$ & & & 1.2 & 2.1 & 88.0 \\
\hline Palmer Spring in snow & $\mathrm{C} 01-25$ & $45^{\circ} 20.21^{\prime}$ & $121^{\circ} 42.30^{\prime}$ & 1890 & $7 / 31 / 01$ & & & 0.4 & 1.3 & 84.0 \\
\hline Palmer Spring in river & $\mathrm{C} 01-26$ & $45^{\circ} 20.21^{\prime}$ & $121^{\circ} 42.30^{\prime}$ & 1890 & $7 / 31 / 01$ & & & 1.5 & 1.7 & 81 \\
\hline Salmon River & $\mathrm{C} 01-27$ & $45^{\circ} 20.12^{\prime}$ & $121^{\circ} 42.31^{\prime}$ & 1853 & $7 / 31 / 01$ & & & 6.8 & 6.5 & 81.5 \\
\hline Spring Box nr. Phlox Pt.* & MNH-01-6 & $45^{\circ} 19.03^{\prime}$ & $121^{\circ} 42.95^{\prime}$ & 1542 & $7 / 31 / 01$ & & & 18.0 & 2.6 & 55.4 \\
\hline Still Creek Spring* & MNH-01-7 & $45^{\circ} 18.95^{\prime}$ & $121^{\circ} 43.14^{\prime}$ & 1512 & 8/01/01 & & & 1.2 & 2.7 & 76.3 \\
\hline \multirow[t]{3}{*}{ Still Creek at road } & $\mathrm{C} 01-38$ & $45^{\circ} 19.00^{\prime}$ & $121^{\circ} 43.38^{\prime}$ & 1475 & $8 / 01 / 01$ & & & 60 & 3.6 & 67.6 \\
\hline & C01-39 & & & & & & & 7.2 & 5.3 & 71.6 \\
\hline & $\mathrm{C} 01-40$ & & & & & & & 6.1 & 5.3 & 65.8 \\
\hline Still Creek at road & C01-41 & $45^{\circ} 18.67^{\prime}$ & $121^{\circ} 43.62^{\prime}$ & 1402 & $8 / 01 / 01$ & & & 29.4 & 5.8 & 66.4 \\
\hline Still Creek tributary & $\mathrm{C} 01-42$ & $45^{\circ} 18.39^{\prime}$ & $121^{\circ} 43.96^{\prime}$ & 1274 & $8 / 01 / 01$ & & & 57.8 & 4.6 & 76.4 \\
\hline Still Creek cascade & MNH-01-8 & $45^{\circ} 18.37^{\prime}$ & $121^{\circ} 43.83^{\prime}$ & 1283 & $8 / 01 / 01$ & & & 27.0 & 7.4 & 256 \\
\hline
\end{tabular}


Table 1 (continued).

\begin{tabular}{|c|c|c|c|c|c|c|c|c|c|c|}
\hline & \multirow{2}{*}{$\begin{array}{l}\text { Sample } \\
\text { or ID } \\
\text { No. }\end{array}$} & \multicolumn{2}{|c|}{ Measurement point } & \multirow[b]{2}{*}{$\begin{array}{c}\text { Elev. } \\
\text { m }\end{array}$} & \multirow[b]{2}{*}{ Date } & \multicolumn{2}{|l|}{ Feature } & \multirow[b]{2}{*}{$\begin{array}{l}\text { Flow } \\
\text { L/s }\end{array}$} & \multirow[b]{2}{*}{$\begin{array}{l}\mathrm{T} \\
{ }^{\circ} \mathrm{C}\end{array}$} & \multirow[b]{2}{*}{$\begin{array}{l}\text { Cond. } \\
\mu \mathrm{S} / \mathrm{cm}\end{array}$} \\
\hline & & Lat. & Lon. & & & Lat. & Lon. & & & \\
\hline \multicolumn{11}{|l|}{ Swim Warm Springs } \\
\hline E. side of pool* & $\mathrm{C} 02-01$ & $45^{\circ} 17.80^{\prime}$ & $121^{\circ} 44.24^{\prime}$ & 1158 & $7 / 24 / 02$ & & & 0.1 & 25.7 & 1222 \\
\hline Still Creek & $\mathrm{C} 02-02$ & $45^{\circ} 17.77^{\prime}$ & $121^{\circ} 44.21^{\prime}$ & 1158 & $7 / 24 / 02$ & & & 74 & 10.5 & 194.2 \\
\hline Below swimming pool & $\mathrm{C} 02-03$ & $45^{\circ} 17.78^{\prime}$ & $121^{\circ} 44.26^{\prime}$ & 1158 & $7 / 24 / 02$ & $45^{\circ} 17.80^{\prime}$ & $121^{\circ} 44.24^{\prime}$ & 6.0 & 18.4 & 618 \\
\hline Pipeline by swimming pool* & $\mathrm{C} 02-04$ & $45^{\circ} 17.81^{\prime}$ & $121^{\circ} 44.24^{\prime}$ & 1158 & $7 / 24 / 02$ & & & 5 & 18.4 & 563 \\
\hline Still Creek above Swim & $\mathrm{C} 02-05$ & $45^{\circ} 17.87^{\prime}$ & $121^{\circ} 44.17^{\prime}$ & 1167 & $7 / 24 / 02$ & & & 225 & 7.6 & 116.3 \\
\hline \multicolumn{11}{|l|}{ Meadows area } \\
\hline Meadows Spring* & $\mathrm{C} 02-06$ & $45^{\circ} 20.37^{\prime}$ & $121^{\circ} 40.05^{\prime}$ & 1798 & $7 / 25 / 02$ & & & 5.0 & 6.3 & 305 \\
\hline Stream from Meadows Spring & $\mathrm{C} 02-07$ & $45^{\circ} 20.31^{\prime}$ & $121^{\circ} 40.05^{\prime}$ & 1743 & $7 / 25 / 02$ & $45^{\circ} 20.37^{\prime}$ & $121^{\circ} 40.05^{\prime}$ & 40 & 7.6 & 300 \\
\hline Stream from E. Meadows Spring & $\mathrm{C} 02-08$ & $45^{\circ} 20.27^{\prime}$ & $121^{\circ} 39.92^{\prime}$ & 1743 & $7 / 25 / 02$ & $45^{\circ} 20.34^{\prime}$ & $121^{\circ} 39.91^{\prime}$ & 3.6 & 3.2 & 120.0 \\
\hline Main Meadows stream - lower & $\mathrm{C} 02-09$ & $45^{\circ} 20.16^{\prime}$ & $121^{\circ} 40.01^{\prime}$ & 1695 & $7 / 25 / 02$ & & & 24.0 & 8.1 & 281 \\
\hline Umbrella Falls & $\mathrm{C} 02-10$ & $45^{\circ} 19.75^{\prime}$ & $121^{\circ} 39.53^{\prime}$ & 1597 & $7 / 25 / 02$ & & & 216 & 11.5 & 105.3 \\
\hline Stream & $\mathrm{C} 02-11$ & $45^{\circ} 19.75^{\prime}$ & $121^{\circ} 39.40^{\prime}$ & 1603 & $7 / 25 / 02$ & & & 21.6 & 16.8 & 15.0 \\
\hline Stream & $\mathrm{C} 02-12$ & $45^{\circ} 19.76^{\prime}$ & $121^{\circ} 38.75^{\prime}$ & 1524 & $7 / 25 / 02$ & & & 3.2 & 5.9 & 38.2 \\
\hline \multicolumn{11}{|l|}{ Swim Warm Springs } \\
\hline E. side of pool* & $\mathrm{C} 02-13$ & $45^{\circ} 17.80^{\prime}$ & $121^{\circ} 44.24^{\prime}$ & 1158 & $7 / 26 / 02$ & & & & 25.2 & 1256 \\
\hline Pipeline by swimming pool* & $\mathrm{C} 02-14$ & $45^{\circ} 17.81^{\prime}$ & $121^{\circ} 44.24^{\prime}$ & 1158 & $7 / 26 / 02$ & & & & 17.2 & 569 \\
\hline Spring nr. Cascade* & MNH-02-1 & $45^{\circ} 18.32^{\prime}$ & $121^{\circ} 43.75^{\prime}$ & 1311 & $7 / 26 / 02$ & & & 2.0 & 6.8 & 234 \\
\hline Salmon River & $\mathrm{C} 02-17$ & $45^{\circ} 20.21^{\prime}$ & $121^{\circ} 42.30^{\prime}$ & 1853 & $7 / 26 / 02$ & & & 45 & 2.2 & 360 \\
\hline Palmer Spring Box* & $\mathrm{C} 02-18$ & $45^{\circ} 20.18^{\prime}$ & $121^{\circ} 42.32^{\prime}$ & 1884 & $7 / 26 / 02$ & & & 2.4 & 2.1 & 52.6 \\
\hline Palmer Spring* & $\mathrm{C} 02-19$ & $45^{\circ} 20.13^{\prime}$ & $121^{\circ} 42.35^{\prime}$ & 1865 & $7 / 26 / 02$ & & & 0.9 & 2.4 & 55.8 \\
\hline
\end{tabular}


Table 1 (continued) Locations in 2003 from GPS unit and differ from earlier estimated locations.

\begin{tabular}{|c|c|c|c|c|c|c|c|c|c|}
\hline & \multirow{2}{*}{$\begin{array}{l}\text { Sample } \\
\text { or ID } \\
\text { No. }\end{array}$} & \multicolumn{2}{|c|}{ Measurement point } & \multirow[b]{2}{*}{$\begin{array}{c}\text { Elev. } \\
\text { m }\end{array}$} & \multirow[b]{2}{*}{ Date } & Feature & \multirow[b]{2}{*}{$\begin{array}{l}\text { Flow } \\
\text { L/s }\end{array}$} & \multirow[b]{2}{*}{$\begin{array}{l}\mathrm{T} \\
{ }^{\circ} \mathrm{C}\end{array}$} & \multirow[b]{2}{*}{$\begin{array}{l}\text { Cond. } \\
\mu S / \mathrm{cm}\end{array}$} \\
\hline & & Lat. & Lon. & & & Lon. & & & \\
\hline \multicolumn{10}{|l|}{ Meadows area } \\
\hline Meadows Spring* & C03-11 & $45^{\circ} 20.26^{\prime}$ & $121^{\circ} 40.21^{\prime}$ & 1761 & $8 / 22 / 03$ & & & 6.5 & 343 \\
\hline Main Meadows stream - lower & $\mathrm{C} 03-12$ & $45^{\circ} 20.15^{\prime}$ & $121^{\circ} 40.12^{\prime}$ & 1745 & $8 / 22 / 03$ & & 50 & 7.2 & 328 \\
\hline Spring nr. Cascade* & $\mathrm{C} 03-13$ & $45^{\circ} 18.25^{\prime}$ & $121^{\circ} 43.73^{\prime}$ & 1279 & $8 / 22 / 03$ & & & 7.0 & 262 \\
\hline \multicolumn{10}{|l|}{ Swim Warm Springs } \\
\hline E. side of pool* & C03-14 & $45^{\circ} 17.74^{\prime}$ & $121^{\circ} 44.27^{\prime}$ & 1176 & $8 / 22 / 03$ & & & 25.4 & 1225 \\
\hline Below swimming pool & $\mathrm{C} 03-15$ & & & & $8 / 22 / 03$ & & & 17.5 & 679 \\
\hline Pipeline by swimming pool* & $\mathrm{C} 03-16$ & & & & $8 / 22 / 03$ & & & 17.5 & 601 \\
\hline
\end{tabular}




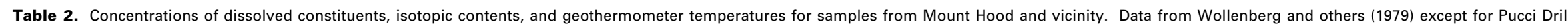
Hole (R. H. Mariner, unpublished data, 1981) and Parkdale Well (Oregon Department of Geology and Mineral Industries, unpublished data, 1978; Bliss, 1983). Isotopic data by N. L. Nehring, L. Merlivat, and J.Borthwick. Geothermometers are from Fournier (1981), Giggenbach (1986), and Kharaka and Mariner (1989).

\begin{tabular}{|c|c|c|c|c|c|c|c|c|c|c|c|c|c|c|c|c|c|c|c|c|c|c|c|c|}
\hline & \multirow[b]{2}{*}{ Lat. $^{\mathrm{e}}$} & \multirow[b]{2}{*}{ Lon. ${ }^{\mathrm{e}}$} & \multirow[b]{2}{*}{$\begin{array}{c}\text { Elev. } \\
\mathrm{m}\end{array}$} & \multirow[b]{2}{*}{$\begin{array}{l}\text { Samp. } \\
\text { No. }\end{array}$} & \multirow[b]{2}{*}{ Date } & \multirow[b]{2}{*}{$\begin{array}{l}\mathrm{T} \\
{ }^{\circ} \mathrm{C} \\
\end{array}$} & \multirow[b]{2}{*}{$\mathrm{pH}$} & \multicolumn{9}{|c|}{ Concentrations $(\mathrm{mg} / \mathrm{L})$} & $\mathrm{Li}$ & \multirow[b]{2}{*}{$\begin{array}{l}\delta^{18} \mathrm{O} \\
\mathrm{o} / \mathrm{oo}\end{array}$} & \multicolumn{6}{|c|}{ Geothermometers } \\
\hline & & & & & & & & $\mathrm{SiO}_{2}$ & $\mathrm{Ca} \mathrm{M}$ & $\mathrm{Mg}$ & $\mathrm{Na}$ & $\mathrm{K}$ & $\mathrm{HCO}_{3}$ & $\mathrm{SO}_{4}$ & $\mathrm{Cl}$ & B & $\begin{array}{l}\delta \mathrm{D} \\
\mathrm{o} / \mathrm{oo}\end{array}$ & & $\begin{array}{l}\text { Chal- } \\
\text { ced. }\end{array}$ & $\mathrm{K}-\mathrm{Mg}$ & $\mathrm{Mg}-\mathrm{Li}$ & $\begin{array}{l}\mathrm{Na}-\mathrm{K} \\
-\mathrm{Ca} \\
\end{array}$ & $\begin{array}{l}\mathrm{R}- \\
\text { value }\end{array}$ & $\begin{array}{l}\mathrm{Na}-\mathrm{K} \\
-\mathrm{Ca}-\mathrm{Mg}\end{array}$ \\
\hline $\begin{array}{l}\text { Swim Warm Springs } \\
\text { Pipeline }\end{array}$ & $45^{\circ} 17.89^{\prime}$ & $121^{\circ} 44.10^{\prime}$ & ' 1170 & $\begin{array}{l}\text { MH-4 } \\
\text { MH-39 }\end{array}$ & $\begin{array}{r}12 / 2 / 76 \\
6 / 2 / 77 \\
2 / 22 / 78\end{array}$ & $\begin{array}{l}20 \\
22 \\
21.6\end{array}$ & $\begin{array}{l}7.3 \\
7.5 \\
7.5\end{array}$ & $\begin{array}{l}55.4 \\
75 \\
75\end{array}$ & $\begin{array}{ll}4 & 2 \\
50 & 3 \\
53 & 3\end{array}$ & $\begin{array}{l}29 \\
34 \\
38\end{array}$ & $\begin{array}{l}79 \\
92 \\
92\end{array}$ & $\begin{array}{l}6 \\
7.5 \\
7\end{array}$ & $\begin{array}{l}141 \\
184 \mathrm{~d} \\
211^{\mathrm{d}}\end{array}$ & $\begin{array}{l}1491 \\
1621 \\
1741\end{array}$ & $\begin{array}{l}103 \\
110 \\
102\end{array}$ & $\begin{array}{l}0.3 \\
2.0 \\
0.5\end{array}$ & $\begin{array}{r}0.08 \\
-95.6 \\
-95.0\end{array}$ & $\begin{array}{l}-13.55 \\
-13.33\end{array}$ & $77^{\mathrm{a}}$ & 45 & 28 & 64 & 51.5 & $39^{\mathrm{b}}$ \\
\hline Screen & $45^{\circ} 17.83^{\prime}$ & $121^{\circ} 44.17^{\prime}$ & ' 1164 & $\begin{array}{l}\text { MH-5 } \\
\text { MH-38 }\end{array}$ & $\begin{array}{r}12 / 2 / 76 \\
6 / 2 / 77 \\
2 / 22 / 78\end{array}$ & $\begin{array}{l}25 \\
25 \\
25.5\end{array}$ & $\begin{array}{l}7.3 \\
7.5 \\
7.5\end{array}$ & $\begin{array}{l}71.6 \\
75 \\
78\end{array}$ & $\begin{array}{ll}6 & 4 \\
55 & 3 \\
60 & 4\end{array}$ & $\begin{array}{ll}44 & 1 \\
36 & \\
43 & 1\end{array}$ & $\begin{array}{r}114 \\
95 \\
105\end{array}$ & $\begin{array}{r}10 \\
8 \\
8\end{array}$ & $\begin{array}{l}191 \\
170^{\mathrm{d}} \\
183^{\mathrm{d}}\end{array}$ & $\begin{array}{l}1931 \\
1861 \\
2161\end{array}$ & $\begin{array}{l}139 \\
120 \\
135\end{array}$ & $\begin{array}{l}0.4 \\
1.0 \\
0.5\end{array}$ & $\begin{array}{r}0.12 \\
-98.1 \\
-97.4\end{array}$ & $\begin{array}{l}-13.90 \\
-13.66\end{array}$ & $91^{\mathrm{a}}$ & 51 & 32 & 77 & 53.9 & $30^{\mathrm{b}}$ \\
\hline E. Swim Pool & $45^{\circ} 17.80^{\prime}$ & $121^{\circ} 44.24^{\prime}$ & ' 1158 & $\begin{array}{l}\text { MH-6 } \\
\text { MH-37 }\end{array}$ & $\begin{array}{r}12 / 2 / 76 \\
6 / 2 / 77 \\
2 / 22 / 78\end{array}$ & $\begin{array}{l}25.6 \\
26 \\
26.2\end{array}$ & $\begin{array}{l}7.5 \\
7.5 \\
7.3\end{array}$ & $\begin{array}{l}72.3 \\
80 \\
88\end{array}$ & $\begin{array}{ll}60 & 4 \\
60 & 4 \\
64 & 5\end{array}$ & $\begin{array}{ll}48 & 1 \\
40 & 1 \\
50 & 1\end{array}$ & $\begin{array}{l}136 \\
120 \\
126\end{array}$ & $\begin{array}{c}11.7 \\
9.2 \\
9\end{array}$ & $\begin{array}{l}218 \\
235 \mathrm{~d} \\
247 \mathrm{~d}\end{array}$ & $\begin{array}{l}2051 \\
1891 \\
2221\end{array}$ & $\begin{array}{l}161 \\
140 \\
154\end{array}$ & $\begin{array}{l}0.3 \\
3.0 \\
0.5\end{array}$ & $\begin{array}{r}0.13 \\
-99.2 \\
-99.4\end{array}$ & $\begin{array}{l}-13.85 \\
-13.74\end{array}$ & $91^{\mathrm{a}, \mathrm{c}}$ & 54 & 33 & 83 & 54.5 & $27 \mathrm{~b}$ \\
\hline $\begin{array}{l}\text { Cistern Box } \\
\text { Nr. Cistern Box } \\
\text { Sp. on West Branch Ck. }\end{array}$ & $\begin{array}{l}45^{\circ} 17.81^{\prime} \\
45^{\circ} 17.83^{\prime} \\
45^{\circ} 17.87^{\prime}\end{array}$ & $\begin{array}{l}121^{\circ} 44.24^{\prime} \\
121^{\circ} 44.24^{\prime} \\
121^{\circ} 44.24^{\prime}\end{array}$ & $\begin{array}{l}1158 \\
1164 \\
1170\end{array}$ & $\begin{array}{l}\text { MH-7 } \\
\text { MH-8 } \\
\text { MH-9 }\end{array}$ & $\begin{array}{l}6 / 2 / 77 \\
6 / 2 / 77 \\
6 / 2 / 77\end{array}$ & $\begin{array}{l}20 \\
21 \\
19\end{array}$ & $\begin{array}{l}7.5 \\
7.4 \\
7.5\end{array}$ & $\begin{array}{l}70 \\
80 \\
60\end{array}$ & $\begin{array}{ll}42 & 3 \\
41 & 2 \\
19 & 1\end{array}$ & $\begin{array}{l}30 \\
20 \\
13\end{array}$ & $\begin{array}{l}86 \\
62 \\
36\end{array}$ & $\begin{array}{l}7.2 \\
6.4 \\
3.6\end{array}$ & $\begin{array}{r}156^{\mathrm{d}} \\
79^{\mathrm{d}} \\
82^{\mathrm{d}}\end{array}$ & $\begin{array}{r}156 \\
144 \\
78\end{array}$ & $\begin{array}{l}95 \\
80 \\
25\end{array}$ & $\begin{array}{l}1 \\
2 \\
0.2\end{array}$ & $\begin{array}{l}-93.0 \\
-97.3 \\
-89.7\end{array}$ & $\begin{array}{l}-13.15 \\
-13.80 \\
-13.05\end{array}$ & & & & & & \\
\hline$\frac{\text { Wells }}{\text { Pucci Well (1220 m) }}$ & $45^{\circ} 19.3^{\prime}$ & $121^{\circ} 42.8^{\prime}$ & 1628 & CQ81JR & $7 / 24 / 81$ & 40.8 & 9.2 & 951 & 1103 & 332 & 270 & 25 & 200 & 4102 & $295<$ & $<1$ & $--\quad-104.5$ & -13.46 & 107 & 75 & -- & 170 & 30.7 & 52 \\
\hline $\begin{array}{l}\text { Parkdale Well }(150 \mathrm{~m}) \\
\text { Clear Ck. Picnic well }\end{array}$ & $\begin{array}{l}45^{\circ} 29.8^{\prime} \\
45^{\circ} 21.5^{\prime}\end{array}$ & $\begin{array}{l}121^{\circ} 33.8^{\prime} \\
121^{\circ} 56.1^{\prime}\end{array}$ & $\begin{array}{l}560 \\
442\end{array}$ & $\begin{array}{l}\text { WS78-314 } \\
\text { MH-22 }\end{array}$ & $\begin{array}{r}11 / 29 / 78 \\
8 / 2 / 77\end{array}$ & $\begin{array}{l}24 \\
10\end{array}$ & $\begin{array}{l}8.4 \\
8.5\end{array}$ & $\begin{array}{l}80 \\
54\end{array}$ & $\begin{array}{ll}11 & \\
51 & 2\end{array}$ & 20 & $\begin{array}{r}94 \\
125\end{array}$ & $\begin{array}{l}17 \\
16\end{array}$ & $\begin{array}{r}242 \\
--\end{array}$ & $\begin{array}{c}10 \\
--\end{array}$ & $\begin{array}{l}37 \\
25\end{array}$ & $\begin{array}{l}3 \\
3\end{array}$ & $\begin{array}{l}0.05 \\
--\end{array}$ & & $\begin{array}{l}97 \\
76\end{array}$ & $\begin{array}{l}96 \\
70\end{array}$ & $\begin{array}{c}41 \\
--\end{array}$ & $\begin{array}{r}209 \\
97\end{array}$ & $\begin{array}{l}19.5 \\
35.8\end{array}$ & $\begin{array}{l}97 \\
50\end{array}$ \\
\hline $\begin{array}{l}\text { Springs } \\
\text { Sp. nr. White River } \\
\text { Ski Bowl, artesian well } \\
\text { Robin Hood Quarry Sp. } \\
\text { Robin Hood Quarry Sp. } \\
\text { HWY 35 Sp. } \\
\text { HWY 26 Sp. } \\
\text { Laurel Hill Sp. } \\
\text { Meadows Sp. }\end{array}$ & $\begin{array}{l}45^{\circ} 18.2^{\prime} \\
45^{\circ} 18.1^{\prime} \\
45^{\circ} 20.2^{\prime} \\
\\
45^{\circ} 18.6^{\prime} \\
45^{\circ} 17.4^{\prime} \\
45^{\circ} 18.4^{\prime} \\
45^{\circ} 20.3^{\prime}\end{array}$ & $\begin{array}{l}121^{\circ} 40.4^{\prime} \\
121^{\circ} 46.5^{\prime} \\
121^{\circ} 34.1^{\prime} \\
\\
121^{\circ} 39.7^{\prime} \\
121^{\circ} 44.0^{\prime} \\
121^{\circ} 49.6^{\prime} \\
121^{\circ} 40.1^{\prime}\end{array}$ & $\begin{array}{r}1305 \\
1107 \\
1097 \\
\\
1317 \\
1182 \\
853 \\
1768\end{array}$ & $\begin{array}{l}\text { MH-2 } \\
\text { MH-3 } \\
\text { MH-10 } \\
\text { MH-36 } \\
\text { MH-11 } \\
\text { MH-12 } \\
\text { MH-13 } \\
\text { MH-14 }\end{array}$ & $\begin{array}{r}6 / 1 / 77 \\
6 / 2 / 77 \\
6 / 3 / 77 \\
2 / 22 / 78 \\
6 / 4 / 77 \\
6 / 4 / 77 \\
6 / 4 / 77 \\
6 / 5 / 77\end{array}$ & $\begin{array}{l}3.5 \\
7 \\
7 \\
4 \\
3 \\
5 \\
10 \\
8\end{array}$ & $\begin{array}{l}6.2 \\
8.5 \\
7.5 \\
7.8 \\
6.7 \\
6.9 \\
6.5 \\
7.5\end{array}$ & $\begin{array}{c}-- \\
-- \\
-- \\
10 \\
-- \\
30 \\
-- \\
42\end{array}$ & $\begin{array}{c}2 \\
17 \\
50 \\
43 \\
<0.01 \\
0.11 \\
0.15< \\
19\end{array}$ & $\begin{array}{c}<1 \\
4 \\
5 \\
2 \\
1 \\
2 \\
<0.6 \\
6\end{array}$ & $\begin{array}{l}2.2 \\
16 \\
6 \\
4 \\
1.2 \\
7 \\
2 \\
6.5\end{array}$ & $\begin{array}{c}1 \\
2 \\
<0.2 \\
0.1 \\
0.4 \\
1 \\
<0.4 \\
3.5\end{array}$ & $\begin{array}{c}-- \\
-- \\
91^{\mathrm{d}} \\
-- \\
11^{\mathrm{d}} \\
-- \\
--\end{array}$ & $\begin{array}{r}-- \\
-- \\
-- \\
45 \\
- \\
9 \\
-- \\
--\end{array}$ & $\begin{array}{c}1 \\
2 \\
<0.2 \\
2 \\
<0.1 \\
5 \\
<0.2 \\
6\end{array}$ & $\begin{array}{l}0.5 \\
0.2 \\
0.5 \\
0.5 \\
0.3 \\
0.2 \\
0.5 \\
0.5\end{array}$ & $\begin{array}{r}-84.4 \\
-84.9 \\
-94.3 \\
-90.8 \\
-82.8 \\
-87.2 \\
-78.4 \\
-97.2\end{array}$ & $\begin{array}{l}-12.20 \\
-12.35 \\
-13.15 \\
-12.57 \\
-12.15 \\
-12.70 \\
-11.15 \\
-13.75\end{array}$ & & & & & & \\
\hline $\begin{array}{l}\text { Mt. Hood Snow melt } \\
\text { Mt. Hood Snow melt } \\
\text { Mt. Hood Snow melt }\end{array}$ & & & $\begin{array}{l}1829 \\
2134 \\
2652\end{array}$ & & $\begin{array}{l}2 / 2 / 79 \\
2 / 2 / 79\end{array}$ & & & & & & & & & & & & $\begin{array}{l}-100.5 \\
-100.4 \\
-139.1\end{array}$ & $\begin{array}{l}-14.00 \\
-14.50 \\
-17.81\end{array}$ & & & & & & \\
\hline
\end{tabular}

${ }^{\text {a }}$ Chalcedony temperature is a minimum, because water is a mixture of cold and warm waters.

b Magnesium correction is normally not applied when $\mathrm{R}>50$; geothermometer temperature is usually the same as the spring temperature in that case.

c Sulfate oxygen temperature is $110^{\circ} \mathrm{C}$ on sample MH-6 of same spring (Nehring and others, 1979).

$\mathrm{d}$ Bicarbonate concentration determined by charge balance.

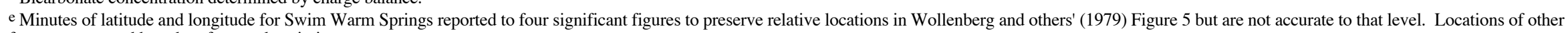
features corrected based on feature descriptions. 


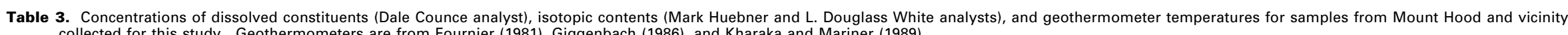

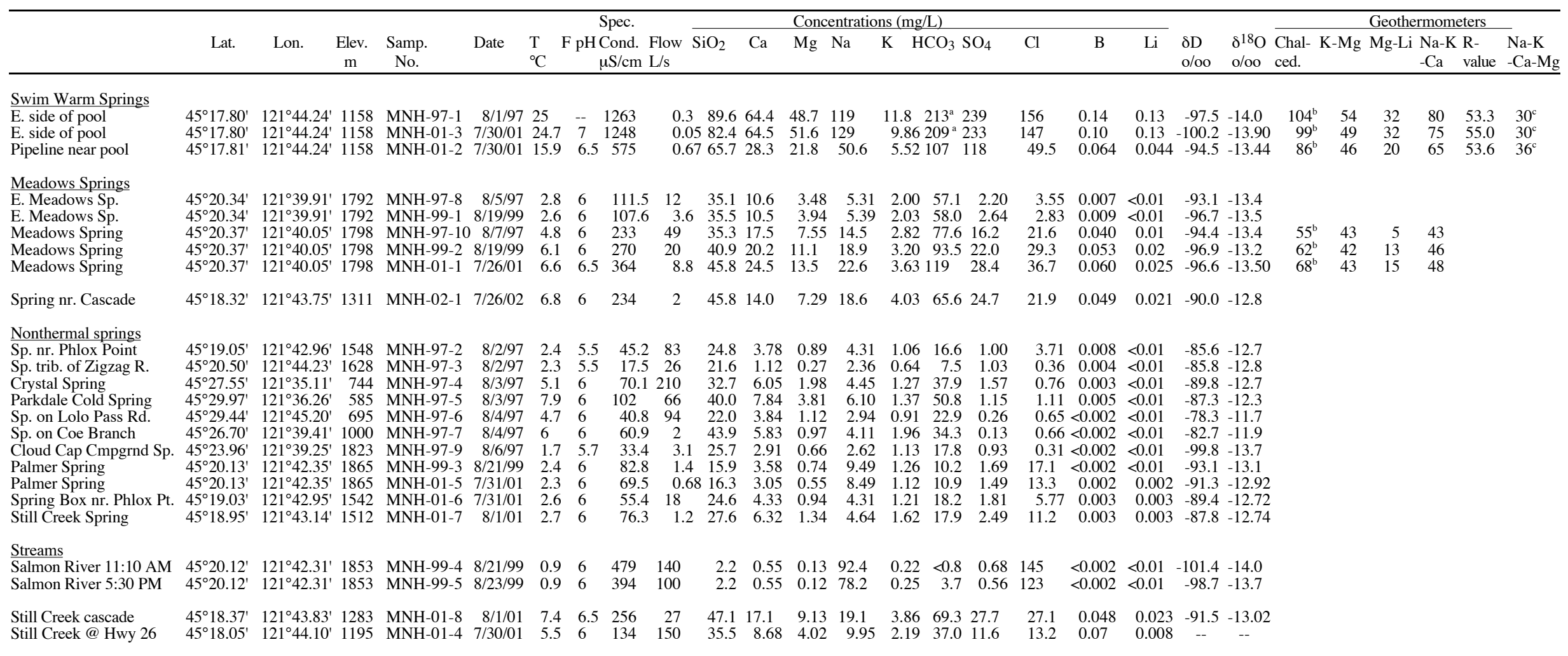

a Carbonate reported as bicarbonate for MNH-97-1 $14.9 \mathrm{mg} / \mathrm{L}$ and MNH-01-3 $11.0 \mathrm{mg} / \mathrm{L}$

$\mathrm{b}$ Chalcedony temperature is a minimum, because water is a mixture of cold and warm waters.

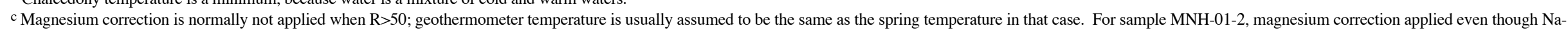
K-Ca temperature $<70^{\circ} \mathrm{C}$ 
Table 3 (continued). Concentrations of dissolved constituents (Dale Counce analyst).

\begin{tabular}{|c|c|c|c|c|c|c|c|c|c|c|c|c|c|c|c|c|}
\hline & \multirow[b]{2}{*}{$\begin{array}{l}\text { Samp. } \\
\text { No. }\end{array}$} & \multirow[b]{2}{*}{ Date } & \multirow[b]{2}{*}{$\mathrm{L}$ pH } & \multicolumn{13}{|c|}{ Concentrations $(\mathrm{mg} / \mathrm{L})$} \\
\hline & & & & $\mathrm{Al}$ & As & $\mathrm{Ba}$ & $\mathrm{Br}$ & Cs & $\mathrm{F}$ & $\mathrm{Hg}$ & $\mathrm{NO}_{3}$ & $\mathrm{Rb}$ & $\mathrm{Sr}$ & $\mathrm{U}$ & V & $\mathrm{Zn}$ \\
\hline \multicolumn{17}{|l|}{ Swim Warm Springs } \\
\hline E. side of pool & MNH-97-1 & $8 / 1 / 97$ & 8.18 & 0.03 & 0.0012 & 0.048 & 0.30 & & 0.34 & & $<0.02$ & & 0.47 & & 0.002 & $<0.01$ \\
\hline E. side of pool & MNH-01-3 & $7 / 30 / 01$ & 8.02 & 0.002 & 0.0022 & 0.048 & 0.28 & $<0.001$ & 0.35 & 0.00008 & $<0.02$ & 0.024 & 0.40 & 0.0015 & 0.002 & 0.003 \\
\hline Pipeline Sp. & MNH-01-2 & $7 / 30 / 01$ & 7.84 & 0.006 & 0.0012 & 0.014 & 0.04 & $<0.001$ & 0.18 & 0.00007 & 0.05 & 0.011 & 0.18 & $<0.001$ & 0.004 & 0.003 \\
\hline \multicolumn{17}{|l|}{ Meadows Springs } \\
\hline E. Meadows Sp. & MNH-97-8 & $8 / 5 / 97$ & 7.58 & $<0.01$ & 0.0012 & 0.006 & $<0.02$ & & 0.02 & & $<0.02$ & & 0.082 & & $<0.002$ & $<0.01$ \\
\hline E. Meadows Sp. & MNH-99-1 & 8/19/99 & 6.18 & $<0.02$ & $<0.0001$ & 0.005 & $<0.02$ & & 0.02 & & $<0.02$ & & 0.071 & & $<0.002$ & $<0.01$ \\
\hline Meadows Spring & MNH-97-10 & $8 / 7 / 97$ & 7.77 & $<0.01$ & $<0.0002$ & 0.006 & $<0.02$ & & 0.04 & & 0.10 & & 0.12 & & 0.002 & $<0.01$ \\
\hline Meadows Spring & MNH-99-2 & 8/19/99 & 6.32 & $<0.02$ & $<0.0001$ & 0.007 & $<0.02$ & & 0.04 & & $<0.02$ & & 0.12 & & $<0.002$ & $<0.01$ \\
\hline Meadows Spring & MNH-01-1 & $7 / 26 / 01$ & 7.83 & 0.004 & 0.0002 & 0.009 & $<0.02$ & $<0.001$ & 0.03 & 0.00006 & 0.03 & 0.010 & 0.16 & $<0.001$ & 0.002 & 0.004 \\
\hline Spring nr. Cascade* & MNH-02-1 & $7 / 26 / 02$ & 7.67 & 0.001 & $<0.0002$ & 0.004 & $<0.02$ & $<0.001$ & 0.03 & $<0.00005$ & $<0.02$ & 0.009 & 0.089 & 0.0001 & 0.003 & 0.001 \\
\hline \multicolumn{17}{|l|}{ Nonthermal springs } \\
\hline Sp. nr. Phlox Point & MNH-97-2 & $8 / 2 / 97$ & 7.03 & 0.02 & 0.0022 & 0.011 & $<0.02$ & & 0.03 & & 0.16 & & 0.04 & & 0.002 & 0.07 \\
\hline Crystal Spring & MNH-97-4 & $8 / 3 / 97$ & 7.52 & $<0.01$ & $<0.0002$ & 0.004 & $<0.02$ & & 0.03 & & $<0.02$ & & 0.054 & & $<0.002$ & 0.03 \\
\hline Parkdale Cold Spring & MNH-97-5 & $8 / 3 / 97$ & 7.75 & 0.02 & 0.0023 & 0.004 & $<0.02$ & & 0.05 & & 6.76 & & 0.13 & & 0.004 & $<0.01$ \\
\hline Sp. on Lolo Pass Rd. & MNH-97-6 & $8 / 4 / 97$ & 7.23 & 0.01 & 0.0010 & $<0.002$ & $<0.02$ & & 0.02 & & $<0.02$ & & 0.028 & & 0.002 & 0.01 \\
\hline Sp. on Coe Branch & MNH-97-7 & $8 / 4 / 97$ & 7.60 & $<0.01$ & 0.0032 & 0.003 & $<0.02$ & & 0.05 & & $<0.02$ & & 0.068 & & $<0.002$ & $<0.01$ \\
\hline Cloud Cap Cmpgrnd Sp. & MNH-97-9 & $8 / 6 / 97$ & 7.10 & 0.01 & 0.0005 & 0.002 & $<0.02$ & & 0.05 & & $<0.02$ & & 0.027 & & $<0.002$ & $<0.01$ \\
\hline Palmer Spring & MNH-99-3 & $8 / 21 / 99$ & 5.57 & $<0.02$ & $<0.0001$ & 0.004 & $<0.02$ & & 0.01 & & $<0.02$ & & 0.026 & & $<0.002$ & $<0.01$ \\
\hline Palmer Spring & MNH-01-5 & $7 / 31 / 01$ & 6.45 & 0.005 & $<0.0001$ & 0.002 & $<0.02$ & $<0.001$ & $<0.02$ & $<0.00005$ & $<0.02$ & 0.003 & 0.020 & $<0.001$ & $<0.001$ & 0.002 \\
\hline Spring Box nr. Phlox Pt. & MNH-01-6 & $7 / 31 / 01$ & 6.60 & 0.004 & $<0.0001$ & $<0.001$ & $<0.02$ & $<0.001$ & $<0.02$ & $<0.00005$ & $<0.02$ & 0.003 & 0.030 & $<0.001$ & 0.002 & 0.002 \\
\hline Still Creek Spring & MNH-01-7 & $8 / 1 / 01$ & 6.64 & 0.017 & $<0.0001$ & 0.0012 & $2<0.02$ & $<0.001$ & 0.02 & $<0.00005$ & $<0.02$ & 0.004 & 0.041 & $<0.001$ & 0.002 & 0.002 \\
\hline \multicolumn{17}{|l|}{ Streams } \\
\hline Salmon River 11:10 AM & MNH-99-4 & 8/21/99 & 5.36 & $<0.02$ & $<0.0001$ & $<0.002$ & $<0.02$ & & $<0.01$ & & 0.10 & & 0.003 & & $<0.002$ & $<0.01$ \\
\hline Salmon River 5:30 PM & MNH-99-5 & 8/23/99 & 5.45 & $<0.02$ & $<0.0001$ & $<0.002$ & $<0.02$ & & $<0.01$ & & $<0.02$ & & 0.003 & & $<0.002$ & $<0.01$ \\
\hline Still Creek cascade & MNH-01-8 & $8 / 1 / 01$ & 7.66 & 0.003 & 0.0002 & 0.005 & $<0.02$ & $<0.001$ & 0.09 & $<0.00005$ & $<0.02$ & 0.010 & 0.11 & $<0.001$ & 0.004 & 0.003 \\
\hline Still Creek@ Hwy 26 & MNH-01-4 & 7/30/01 & 7.26 & 0.006 & 0.0001 & 0.002 & $<0.02$ & $<0.001$ & 0.03 & $<0.00005$ & $<0.02$ & 0.006 & 0.060 & $<0.001$ & 0.003 & 0.002 \\
\hline
\end{tabular}


Table 4. Gas concentrations without water in mole \% for samples from Mount Hood fumaroles. Samples for 1935 from Phillips (1936), for 1951 from Ayers and Creswell (1951), for 1977 and 1978 from Nehring and others (1981), for 1983 from D. S. Sheppard (unpublished data, 1983), for 1980 and 1995 from Mariner and others (2003), for 1996 from unpublished data from R. Symonds and C. J. Janik (1998), for 1997 from Symonds and others (2003), and for 2002 W. C. Evans, analyst. Geothermometer temperatures TDP from D'Amore and Panichi (1980). Geothermometer uses concentrations of CO2, H2S, $\mathrm{H}_{2}$, and $\mathrm{CH}_{4}$. Where concentration is listed as 0 or less than, a value of $0.001 \%$ is used in the calculation.

\begin{tabular}{|c|c|c|c|c|c|c|c|c|c|c|c|c|}
\hline Date & Sample No. & $\begin{array}{c}\text { Temp } \\
{ }^{\circ} \mathrm{C}\end{array}$ & $\mathrm{CO}_{2}$ & $\mathrm{H}_{2} \mathrm{~S}$ & $\mathrm{H}_{2}$ & $\mathrm{CH}_{4}$ & $\mathrm{~N}_{2}$ & $\mathrm{O}_{2}$ & $\mathrm{He}$ & $\mathrm{Ar}$ & $\mathrm{He}+\mathrm{Ar}$ & $\begin{array}{c}{ }^{\text {TDP }} \\
{ }^{\circ} \mathrm{C}\end{array}$ \\
\hline \multicolumn{13}{|c|}{ Base of Steel Cliff } \\
\hline $10 / 6 / 35$ & D-1 & 89 & 86.9 & 2.92 & 0.25 & 0.085 & 8.99 & 0.85 & & & 0.11 & 225 \\
\hline $5 / 15 / 51$ & D-3 & 89 & 86.8 & 10.7 & 0.27 & 0.038 & 1.94 & 0.22 & & & $0.01^{\mathrm{a}}$ & 253 \\
\hline $5 / 15 / 51$ & D-6 & 89 & 86.9 & 10.5 & 0.24 & 0.033 & 2.04 & 0.25 & & & $0.02^{\mathrm{a}}$ & 250 \\
\hline $7 / 21 / 77$ & MH77-16 & 91 & 91.5 & 4.02 & 0.51 & 0 & 3.87 & 0 & 0.00081 & 0.021 & 0.0218 & 294 \\
\hline \multicolumn{13}{|c|}{ Devils Kitchen } \\
\hline $10 / 6 / 35$ & A-2 & 89 & 93.8 & 1.77 & trace & -- & 4.21 & 0.13 & & & 0.05 & \\
\hline $5 / 15 / 51$ & A-1 & 89 & 89.9 & 4.11 & 3.87 & 0.040 & $1.65^{\mathrm{a}}$ & 0.16 & & & 0.3 & 323 \\
\hline $5 / 15 / 51$ & A-5 & 89 & 89.3 & 4.30 & 4.09 & 0.059 & 1.85 & 0.16 & & & 0.3 & 321 \\
\hline $7 / 21 / 77$ & MH77-15 & 88 & 91.9 & 0.16 & 0.0062 & 0 & 5.61 & 1.26 & 0 & 0.081 & 0.081 & 144 \\
\hline $10 / 4 / 78$ & $78 \mathrm{H}-2 \mathrm{~g}$ & 92 & 94.4 & 3.90 & 1.22 & 0 & 0.46 & 0 & 0 & 0.0018 & 0.0018 & 323 \\
\hline $10 / 4 / 78$ & $78 \mathrm{H}-2 \mathrm{~g}$ Dup. & 92 & 93.2 & 3.67 & 2.22 & 0.0055 & 0.87 & 0 & 0 & 0.0027 & 0.0027 & 323 \\
\hline $7 / 21 / 83$ & & 91 & 87.9 & 2.45 & 1.64 & $<0.001$ & 7.94 & 0 & $<0.0013$ & 0.118 & 0.118 & 328 \\
\hline $5 / 8 / 97$ & 970508-1 & 90.3 & 77.9 & 16.1 & 2.62 & $<0.0005$ & 2.19 & 0.0039 & 0.00291 & 0.0155 & 0.0184 & \\
\hline \multicolumn{13}{|l|}{ Hot Rocks } \\
\hline $5 / 15 / 51$ & 2 & 91 & 90.9 & 2.26 & 4.02 & 0.055 & 2.46 & 0.34 & & & & 309 \\
\hline \multicolumn{13}{|c|}{ Crater Rock } \\
\hline $10 / 6 / 35$ & B-3 & 71 & 0.69 & -- & 0.58 & -- & 79.1 & 19.7 & & & & \\
\hline $5 / 15 / 51$ & B-4 & 86 & 58.4 & 0.000 & trace? & 0.00003 & 32.9 & 8.32 & & & 0.44 & 51 \\
\hline $7 / 21 / 77$ & MH77-17 & 90 & 96.7 & 1.23 & 1.22 & 0 & 0.95 & 0.0082 & 0.025 & 0.0077 & 0.0327 & 301 \\
\hline $10 / 4 / 78$ & 78H-4g Dup. & 91 & 92.7 & 3.69 & 2.76 & 0 & 0.89 & 0 & 0 & 0 & 0 & 354 \\
\hline $10 / 4 / 78$ & $78 \mathrm{H}-4 \mathrm{~g}$ & 91 & 93.3 & 2.63 & 3.21 & 0.0003 & 1.02 & 0 & 0 & 0 & 0 & 370 \\
\hline $8 / 9 / 80$ & & & 93.28 & 3.10 & 2.81 & $<0.002$ & 0.87 & $<0.02$ & $<0.005$ & $<0.02$ & & 351 \\
\hline $7 / 21 / 83$ & & 90 & 91.1 & 0.985 & 2.93 & $<0.0002$ & 4.92 & 0.0018 & $<0.0006$ & 0.066 & 0.066 & 331 \\
\hline $9 / 12 / 95$ & & & 93.15 & 3.50 & $3.23^{\mathrm{c}}$ & $<0.0002$ & 0.92 & 0.042 & -- & 0.0028 & 0.0028 & 360 \\
\hline $10 / 8 / 96$ & $961008-1$ & 89.2 & 90.9 & 4.96 & 2.49 & $<0.00077$ & 1.61 & 0.0018 & 0.00072 & 0.0203 & 0.0210 & 357 \\
\hline $10 / 8 / 96$ & $961008-2$ & 89.2 & 91.3 & 5.07 & 2.22 & $<0.00068$ & 1.38 & 0 & 0.00057 & 0.0168 & 0.0174 & 353 \\
\hline $10 / 8 / 96$ & $961008-8$ & 90.0 & 91.4 & 3.69 & 3.11 & $<0.00093$ & 1.84 & 0 & 0.00074 & 0.0237 & 0.0244 & 360 \\
\hline 9/9/97 & 970909-2 & 91 & 91.69 & 4.55 & 2.13 & $<0.0004$ & 1.21 & 0.0017 & 0.00101 & 0.0101 & 0.0111 & 349 \\
\hline $8 / 29 / 02$ & & 89 & 90.2 & 5.12 & 2.88 & $<0.0002$ & 1.62 & 0.19 & 0.002 & 0.012 & 0.014 & 365 \\
\hline \multicolumn{13}{|c|}{ Ridge west of Devils Kitchen } \\
\hline $10 / 4 / 78$ & $78 \mathrm{H}-1 \mathrm{~g}$ & -- & 6.3 & 0 & 0 & 0 & 70.5 & 17.0 & 0 & $0.84^{b}$ & 0.84 & \\
\hline
\end{tabular}

a Value in Nehring and others (1981) does not agree with recalculation of analysis in Ayers and Creswell (1951).

b Value in Nehring and others (1981) corrected based on original laboratory notes.

c Estimated value based on air corrected ratio of $\mathrm{H}_{2} / \mathrm{CO}_{2}$ from a sample from the same site that was contaiminated with air. 


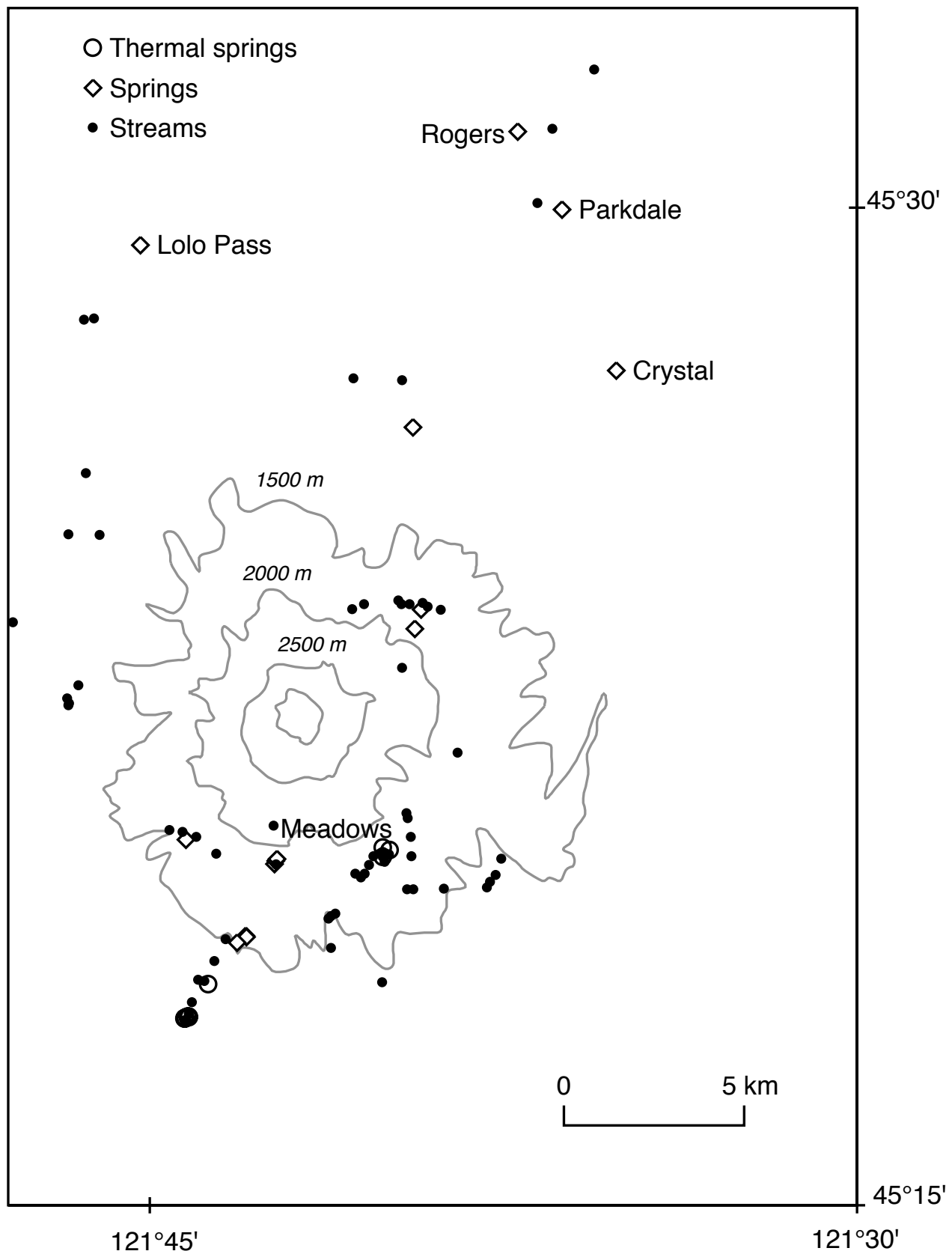

Figure 1. Map of locations of sites visited in this study. Topography of cone is shown above $1500 \mathrm{~m}$. 


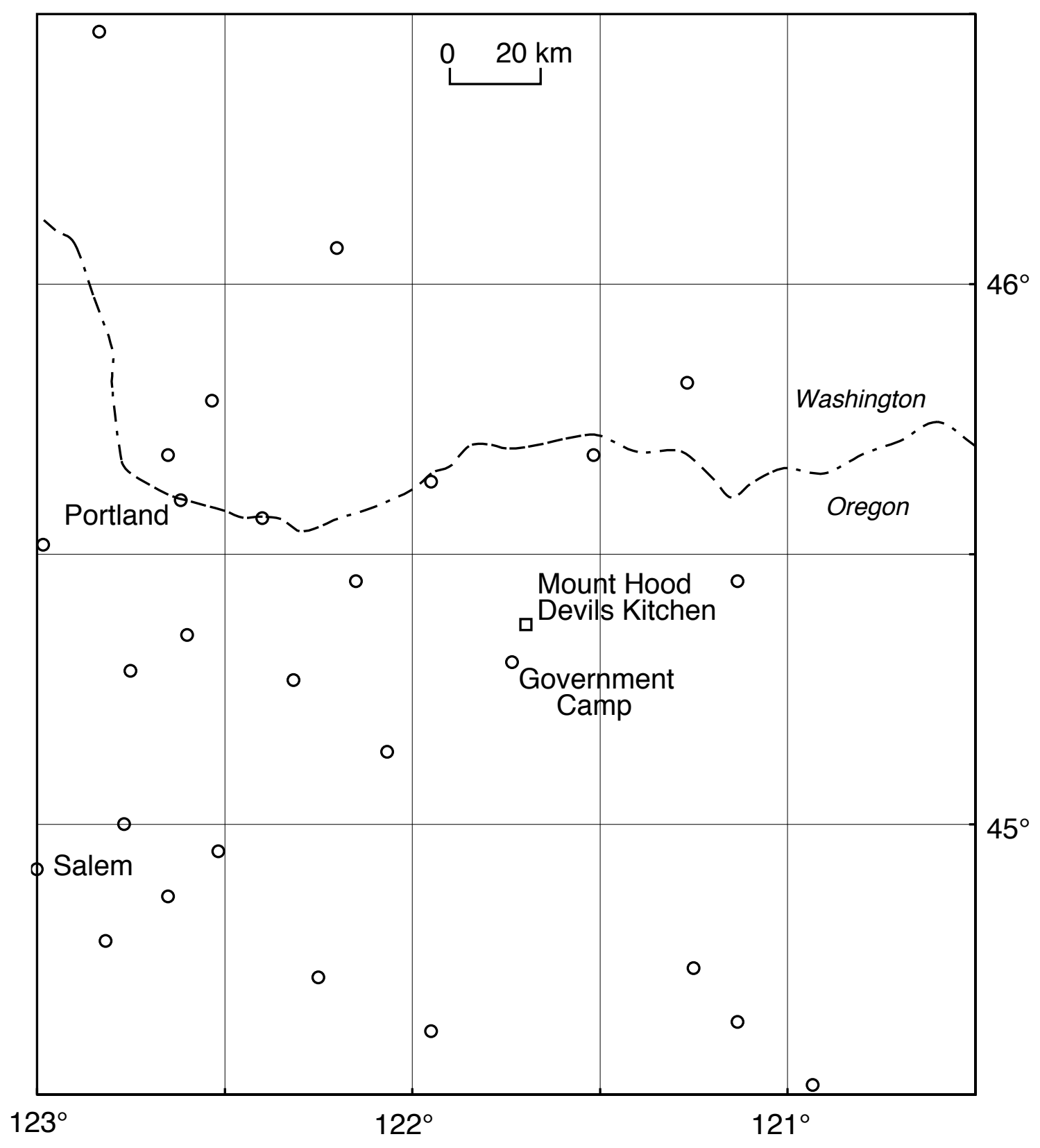

Figure 2. Map of weather stations in the vicinity of Mount Hood with 30-year records for calculation of normal air temperatures. 


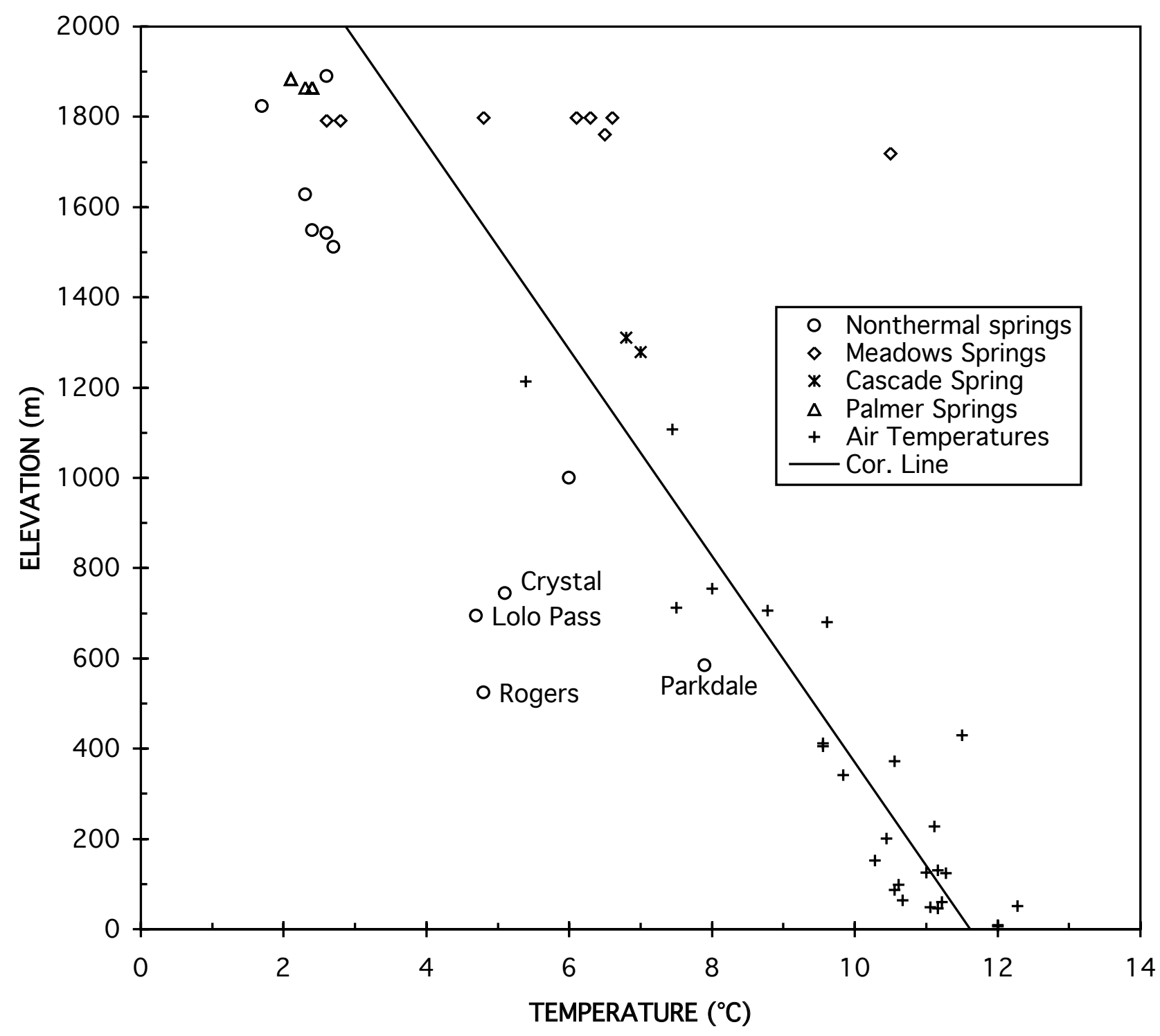

Figure 3. Temperature versus elevation for air temperatures from weather stations shown in Figure 2 and data for temperatures of springs from sites in Figure 1 except for Swim Warm Springs whose values plot beyond the scale of this figure. 


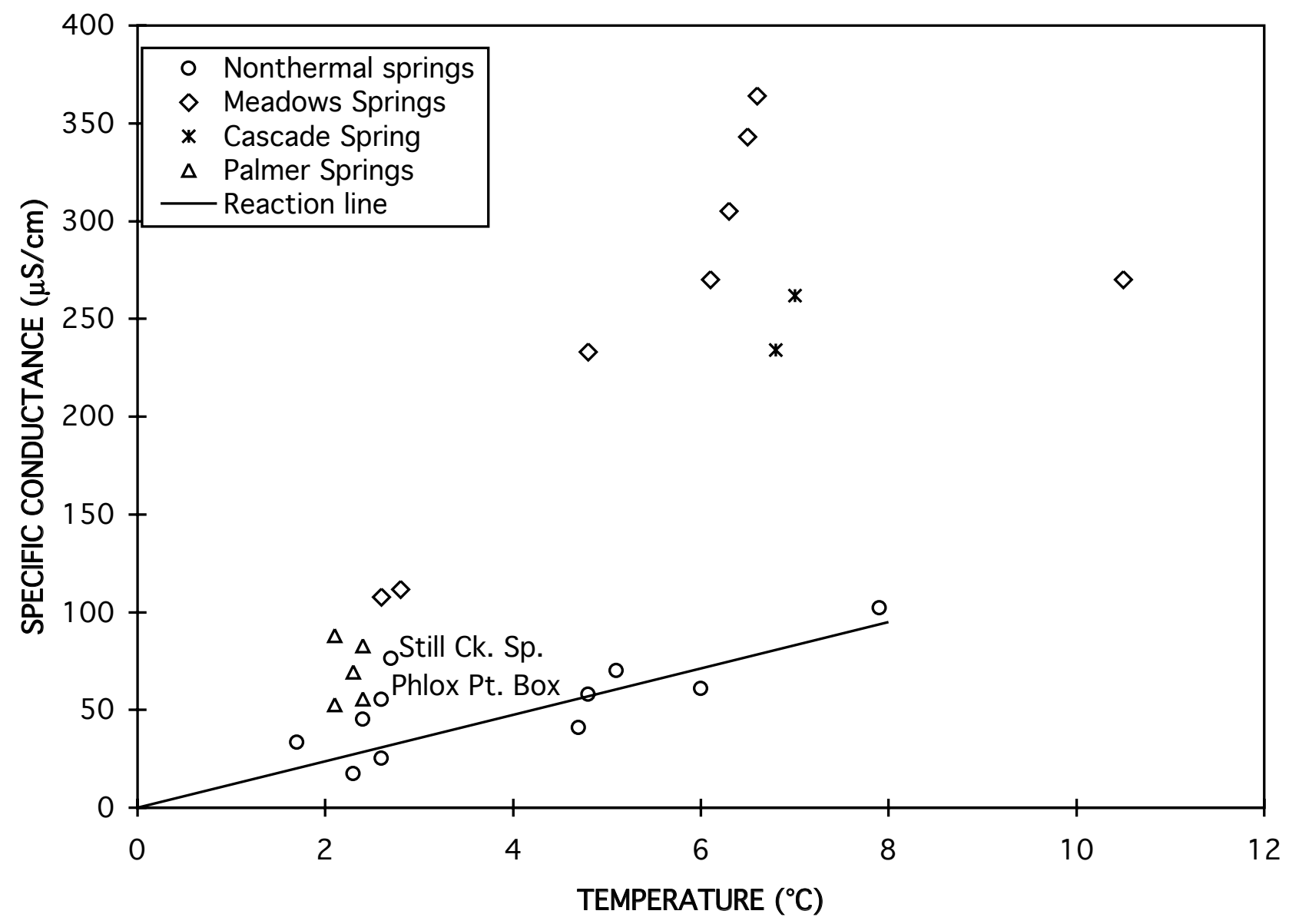

Figure 4. Specific conductance versus temperature of springs from sites in Figure 1 except for Swim Warm Springs whose values plot beyond the scale of this figure. 


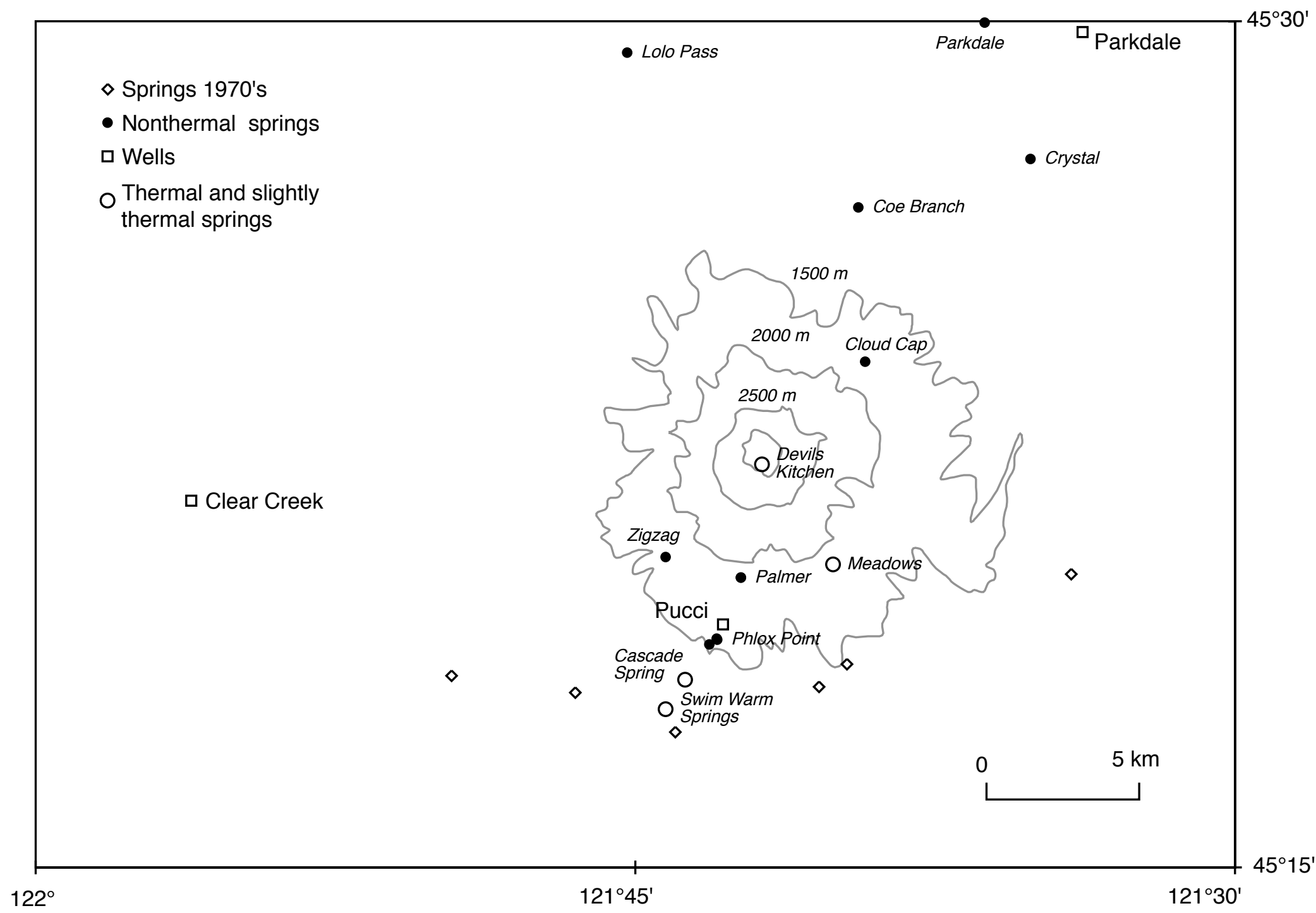

Figure 5. Map of locations of springs and wells with data published earlier (Table 2), nonthermal, thermal, and slightly thermal springs from this study (Table 3). Topography of cone shown above $1500 \mathrm{~m}$. 


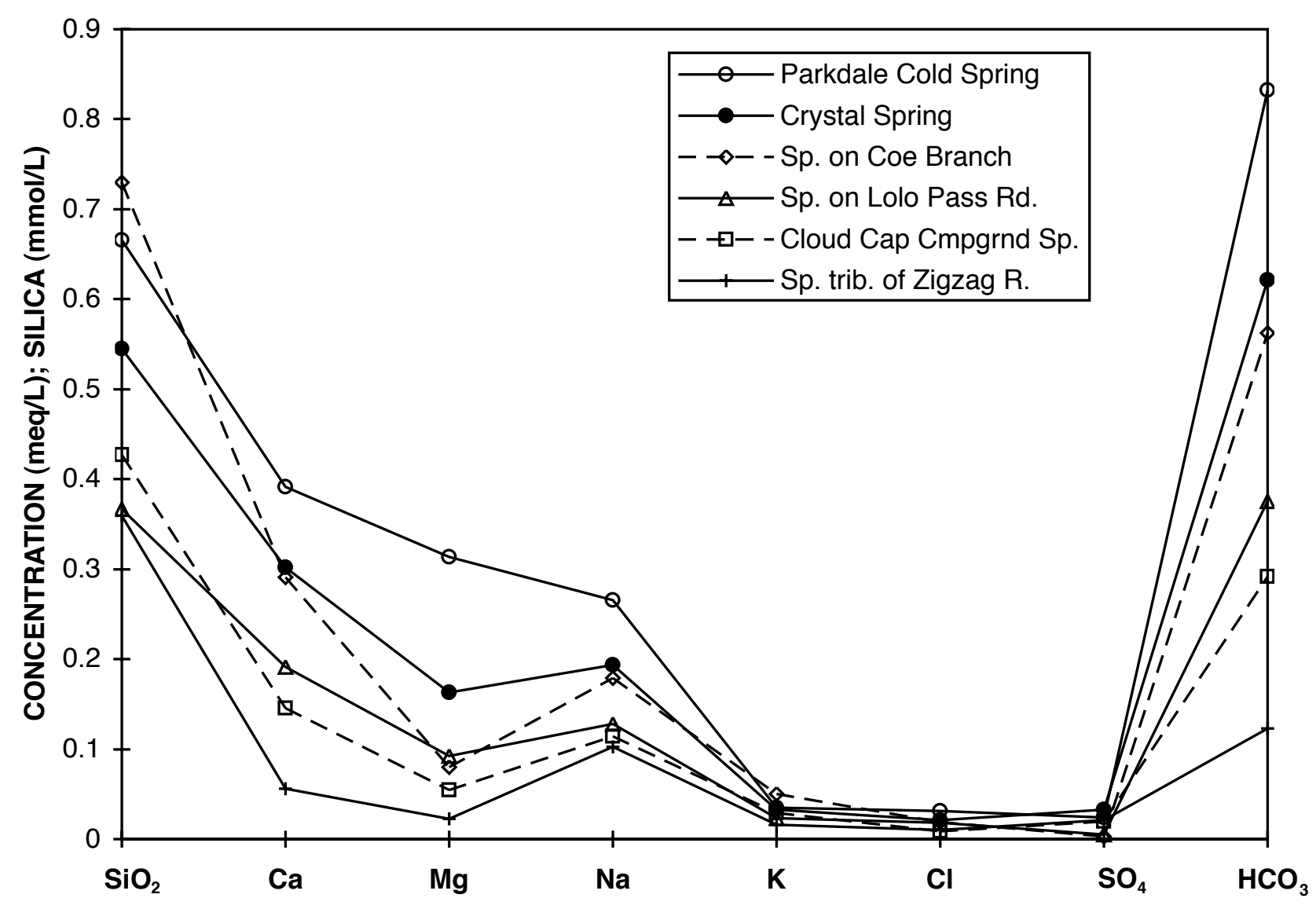

Figure 6. Modified Schoeller diagram for some of the nonthermal springs sampled in this study. 


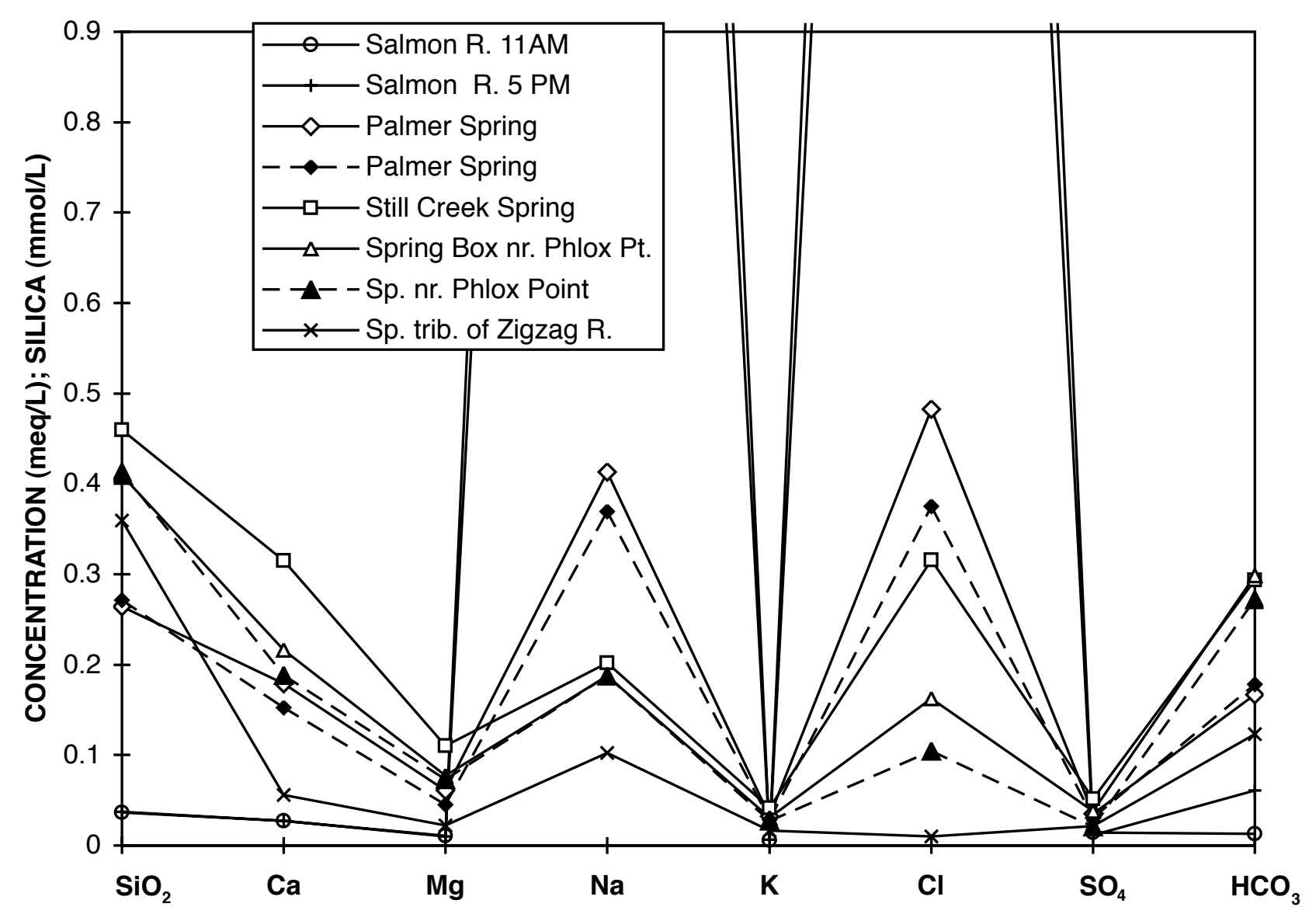

Figure 7. Modified Schoeller diagram for nonthermal springs sampled in this study showing anomalous chloride from salt added to snow, Salmon River samples, and the spring tributary to the Zigzag River for comparison. 


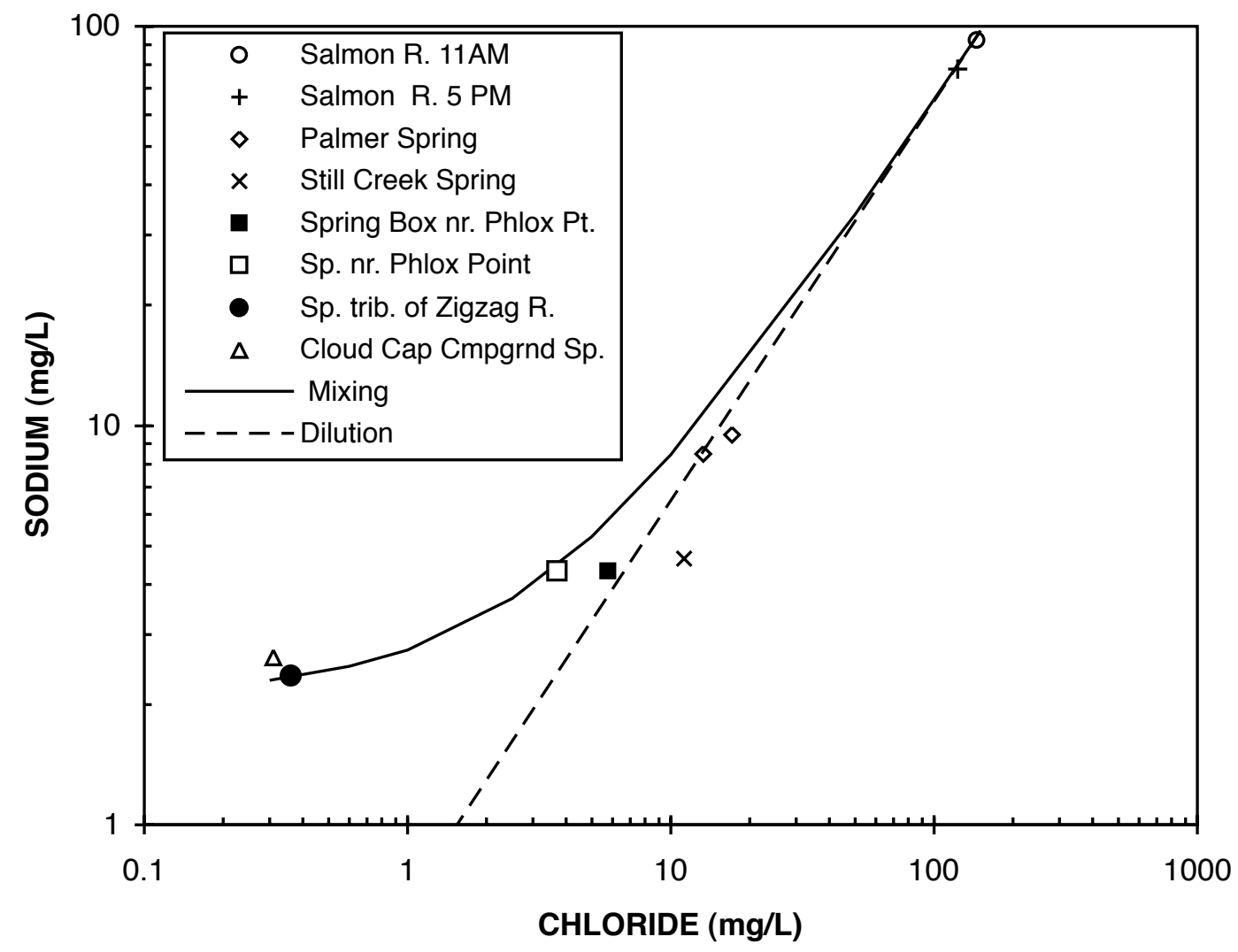

Figure 8. Sodium versus chloride for nonthermal springs sampled in this study showing anomalous chloride from salt added to snow, Salmon River samples, and the spring tributary to the Zigzag River and Cloud Cap Campground Spring for comparison. 


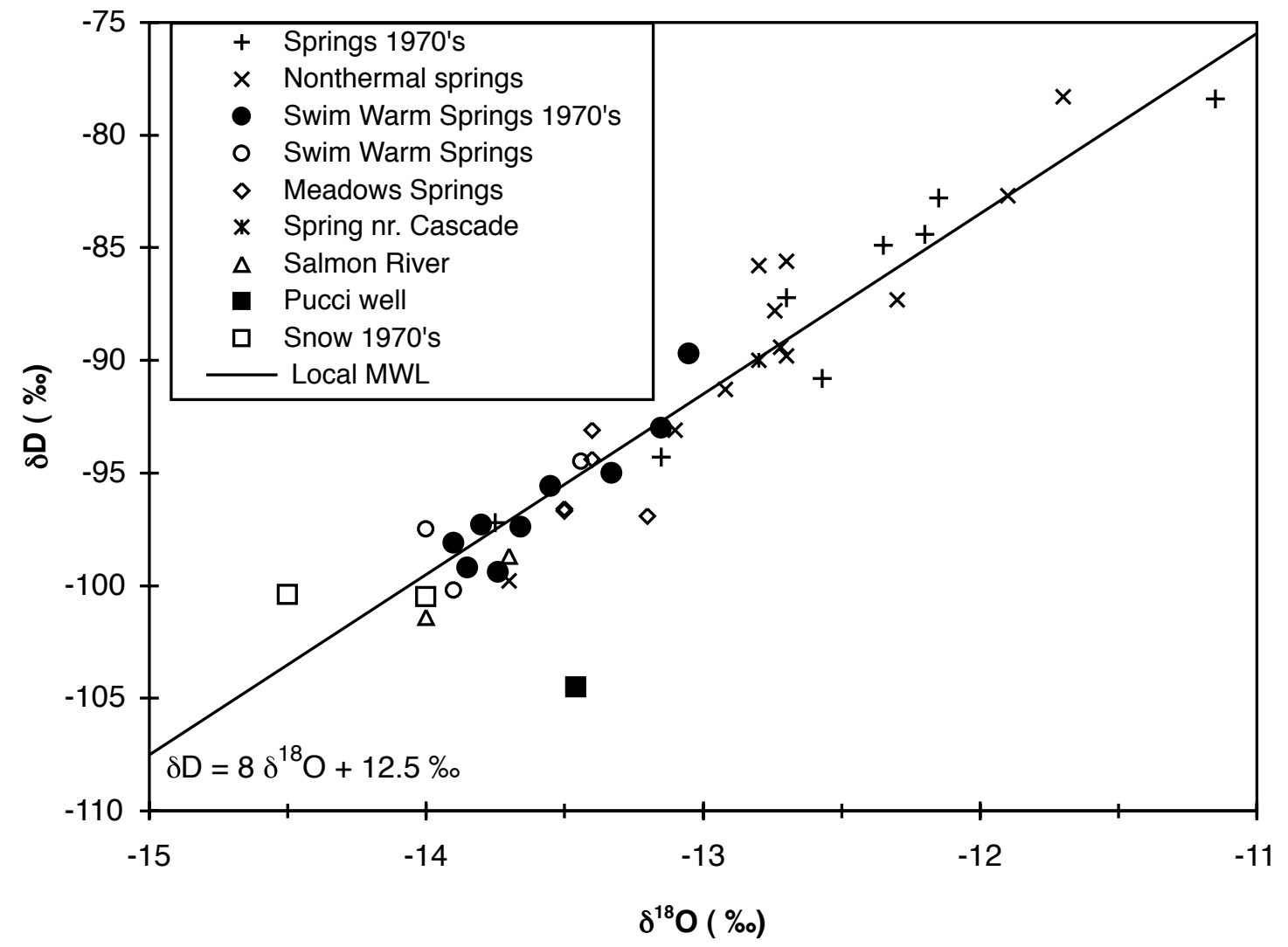

Figure 9. Deuterium versus oxygen-18 for samples from Tables 2 and 3. Local meteoric water line determined by fixing slope at a value of 8 and adjusting the intercept to minimize $\delta \mathrm{D}-8 \delta^{18} \mathrm{O}$ - intercept. 


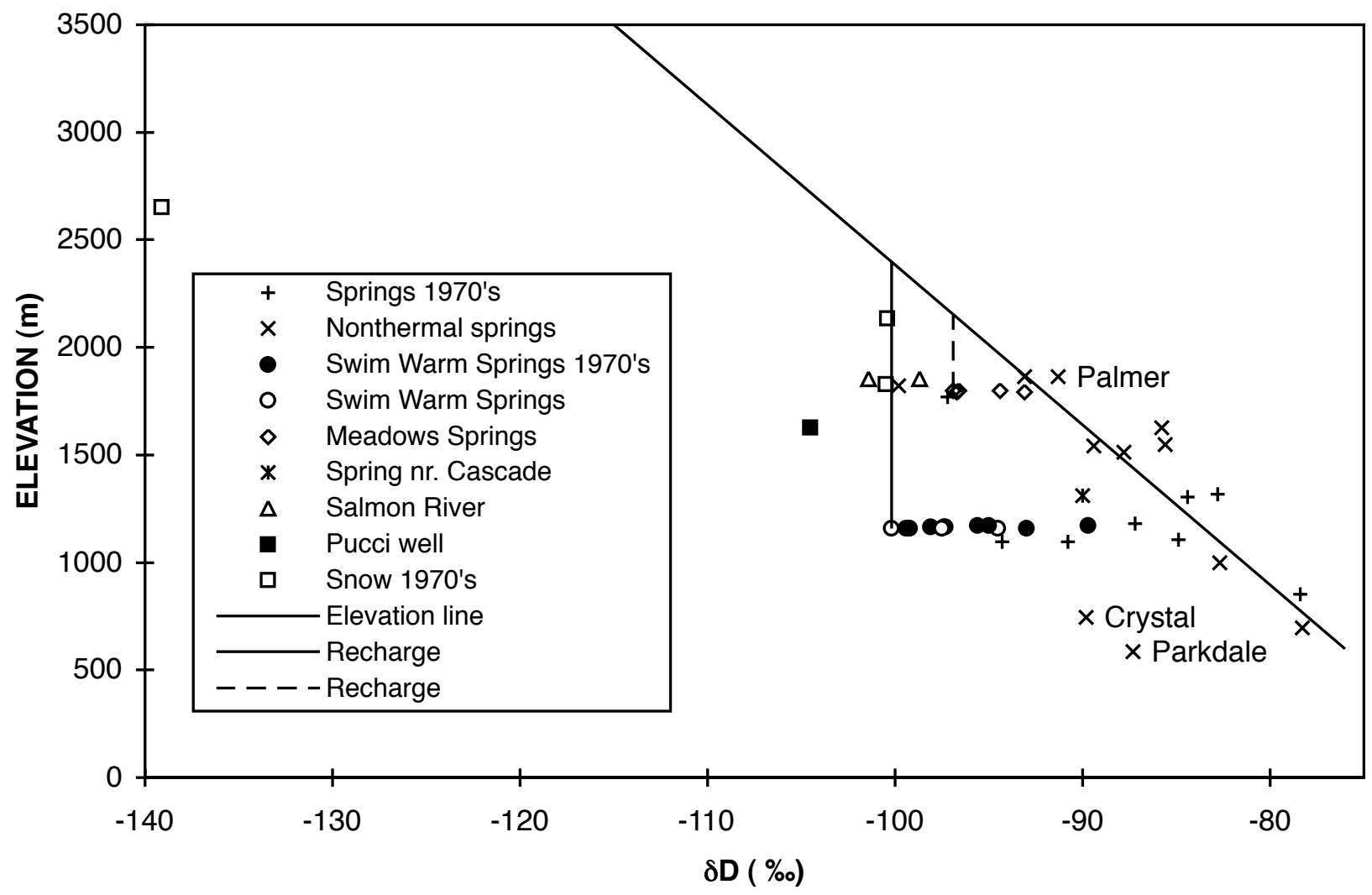

Figure 10. Deuterium versus elevation for samples from Tables 2 and 3.

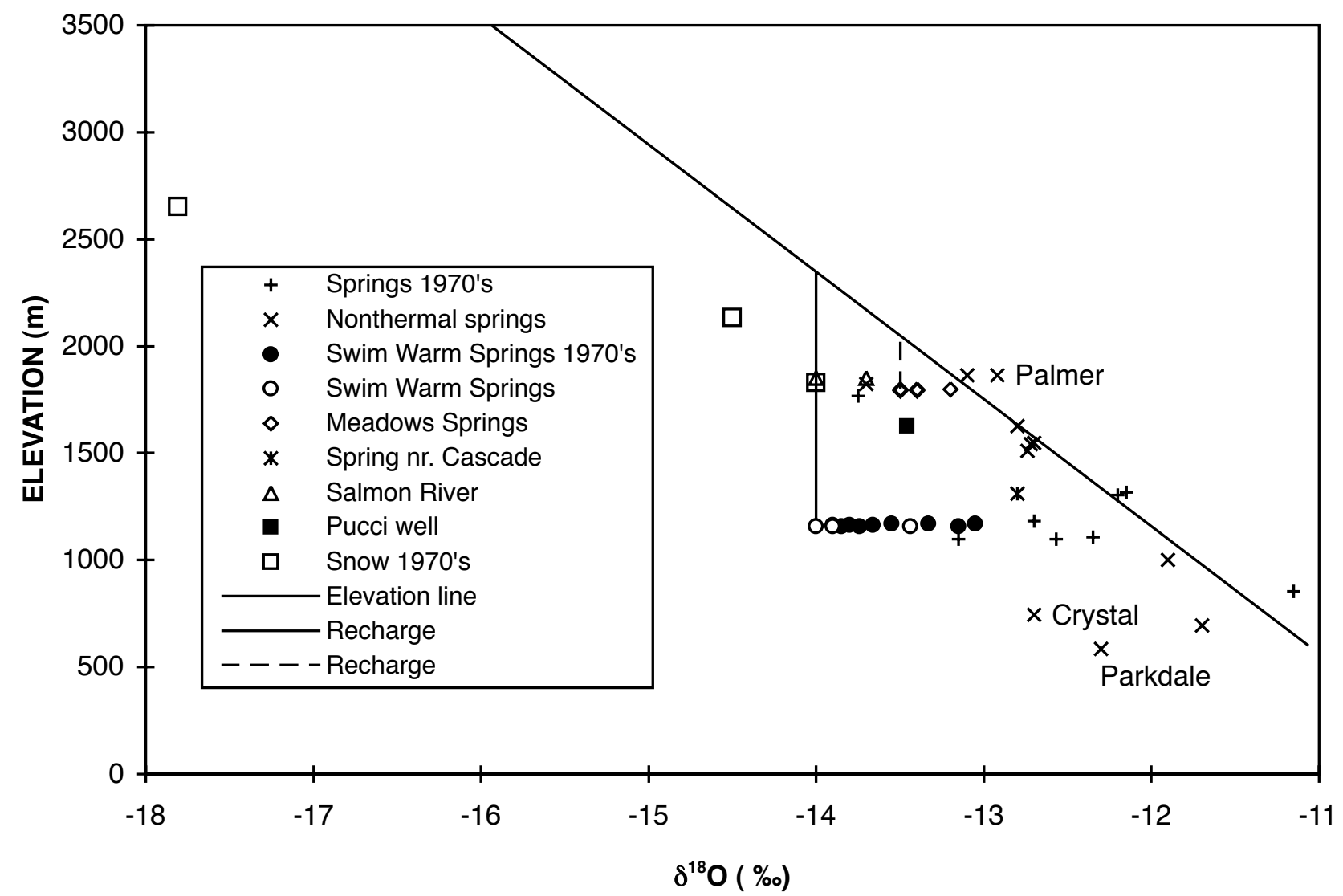

Figure 11. Oxygen-18 versus elevation for samples from Tables 2 and 3. 


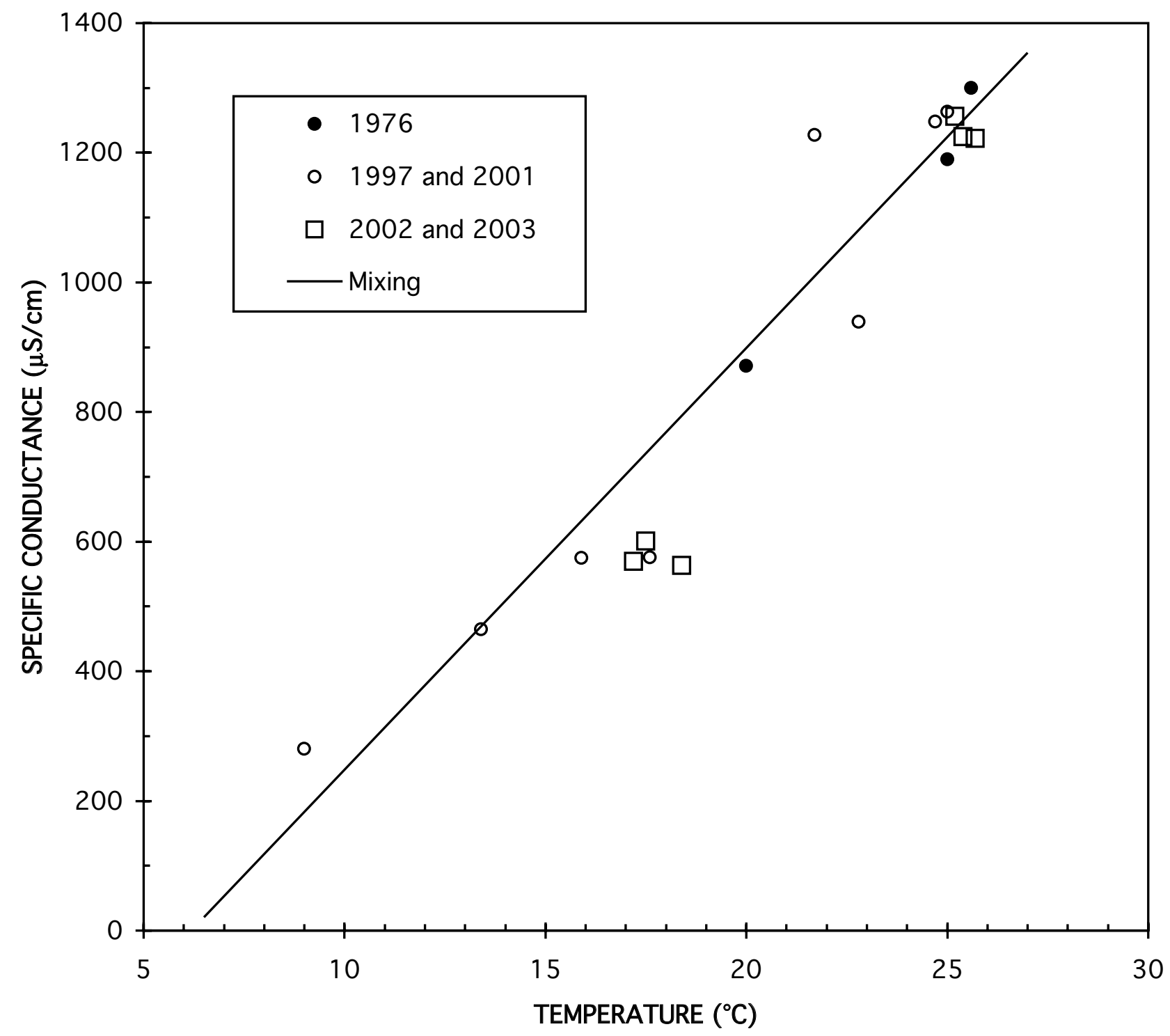

Figure 12. Specific conductance versus spring temperature for various vents of Swim Warm Springs. Data from 2002 and 2003 not included in least-squares line to keep from biasing result from repeated sampling of same two features. 


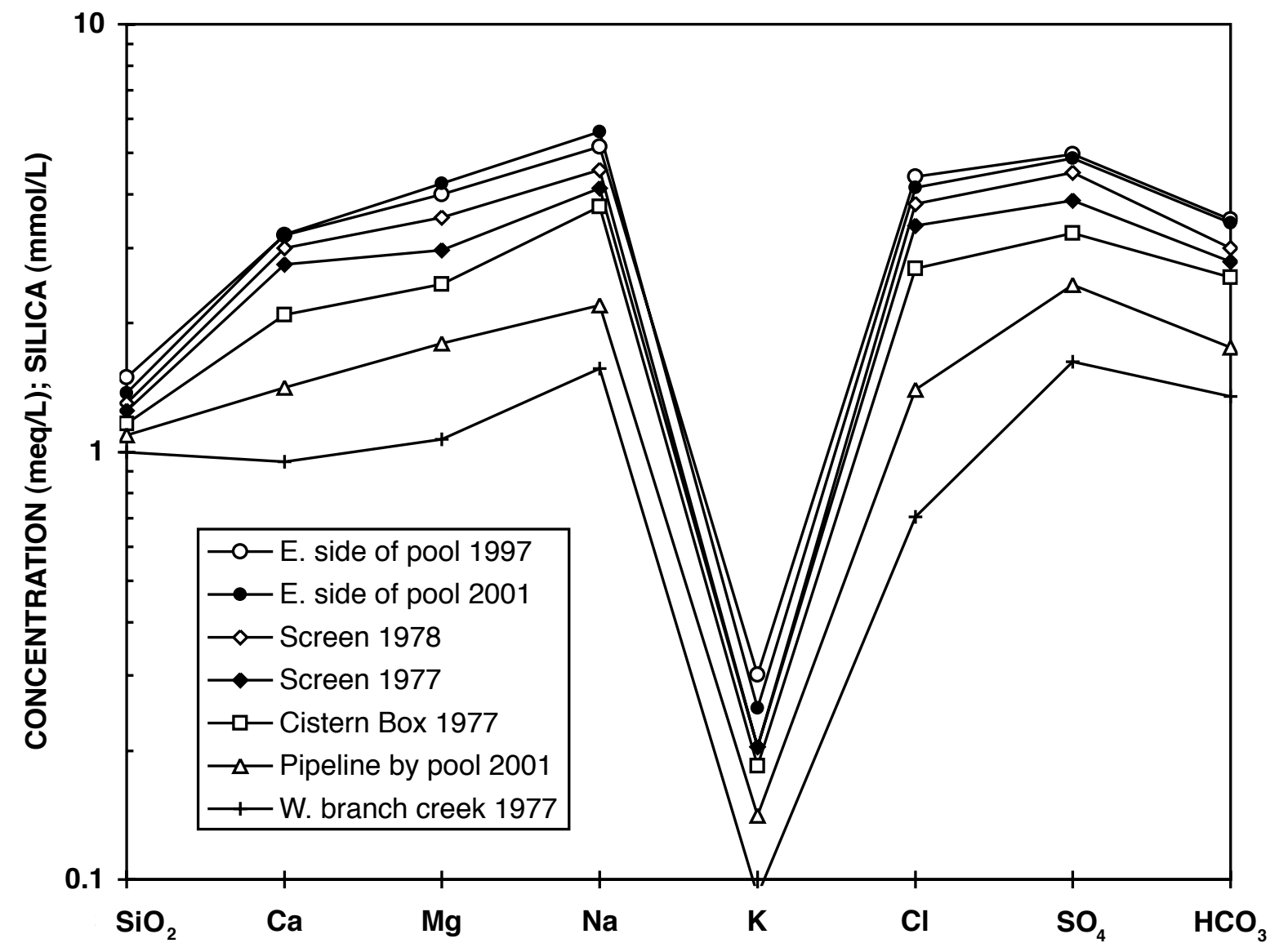

Figure 13. Modified Schoeller diagram (note log scale) for various vents of Swim Warm Springs. 


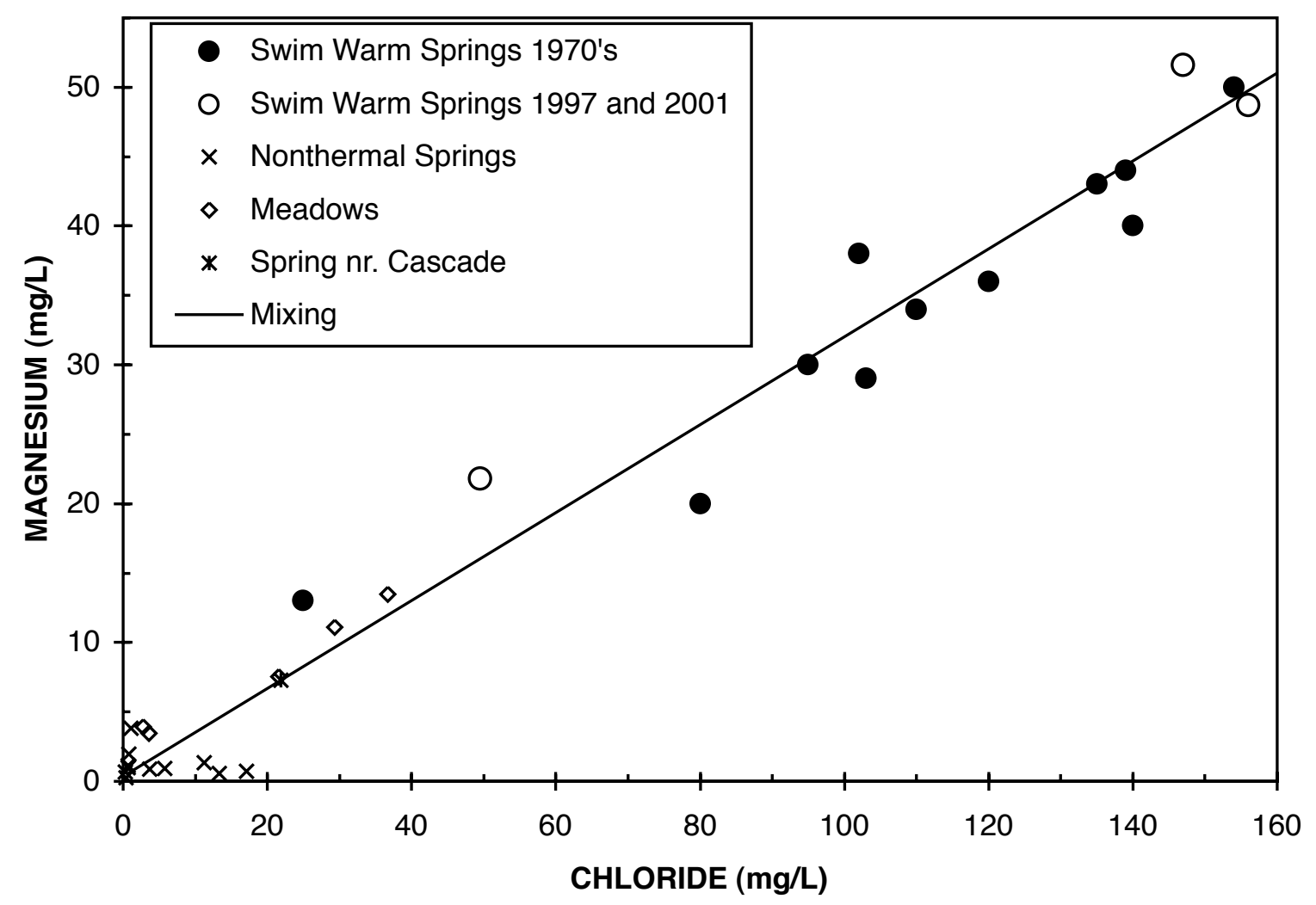

Figure 14. Magnesium versus chloride for springs. Mixing line is for Swim Warm Springs samples. 

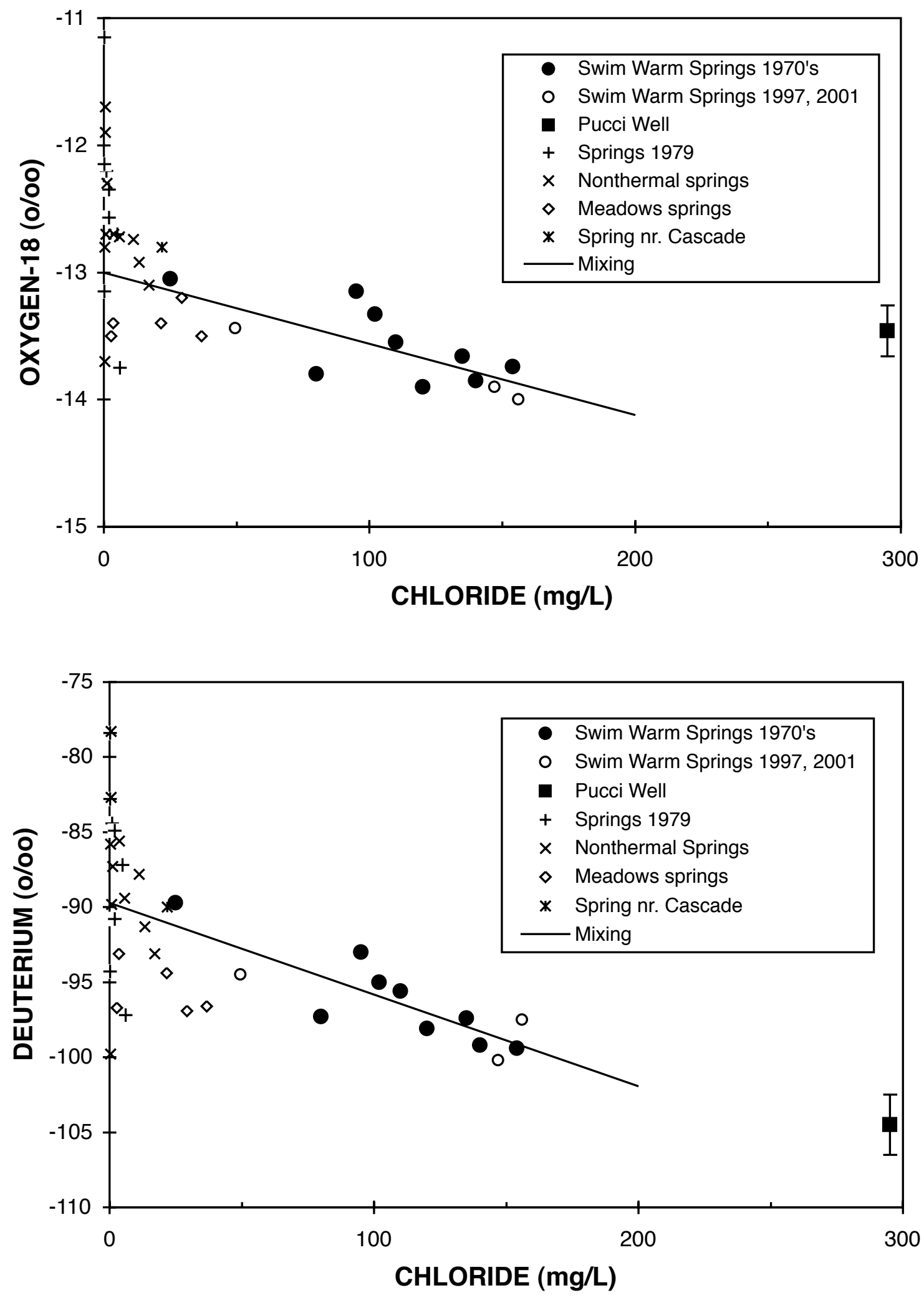

Figure 15. Isotopes versus chloride for springs and other samples. Mixing lines are for Swim Warm Springs samples. Some analyses from 1970's with chloride values given as less than some value have been plotted using the reported value. 


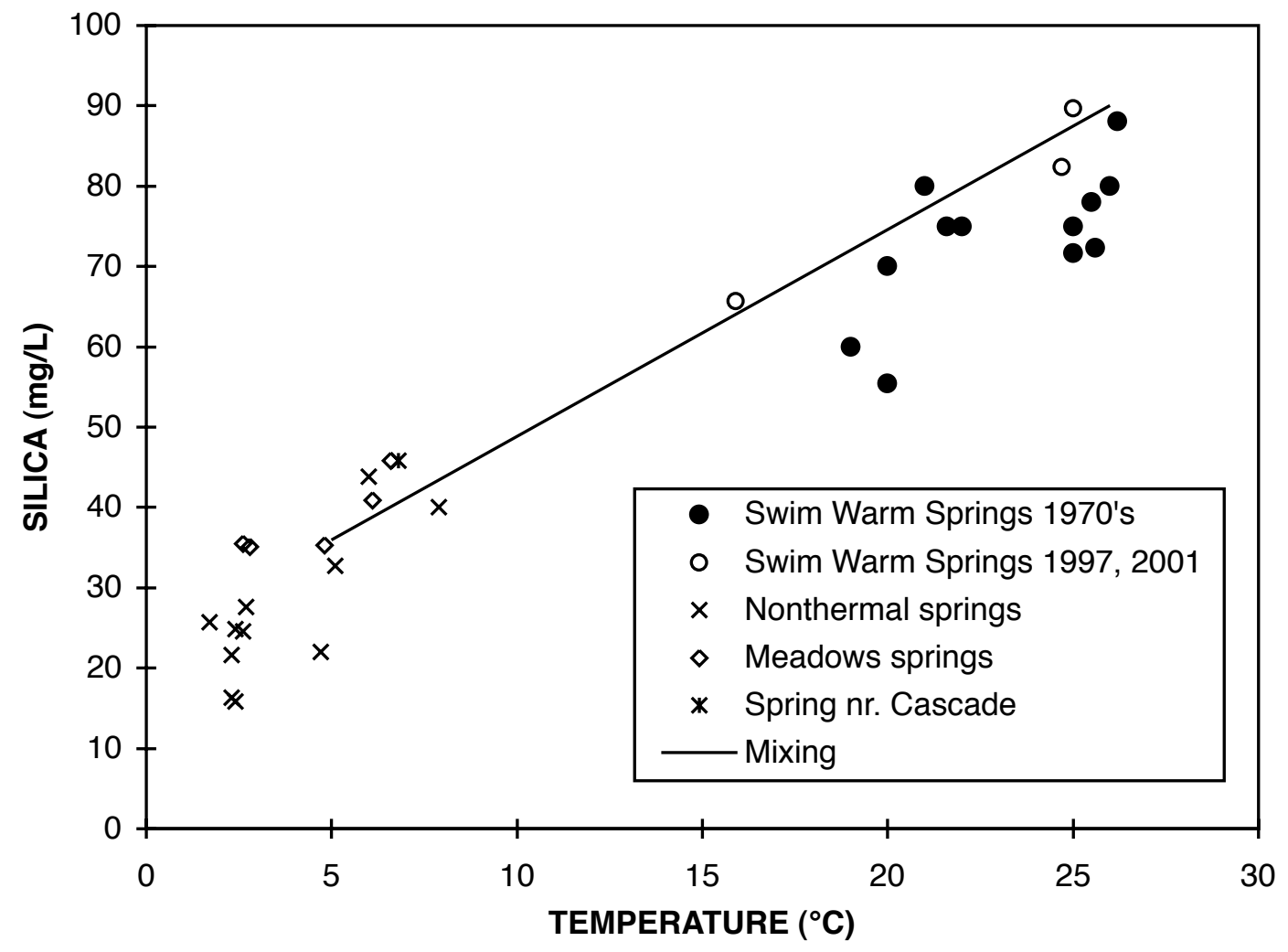

Figure 16. Silica versus spring temperature for springs. Mixing line is for Swim Warm Springs samples. 


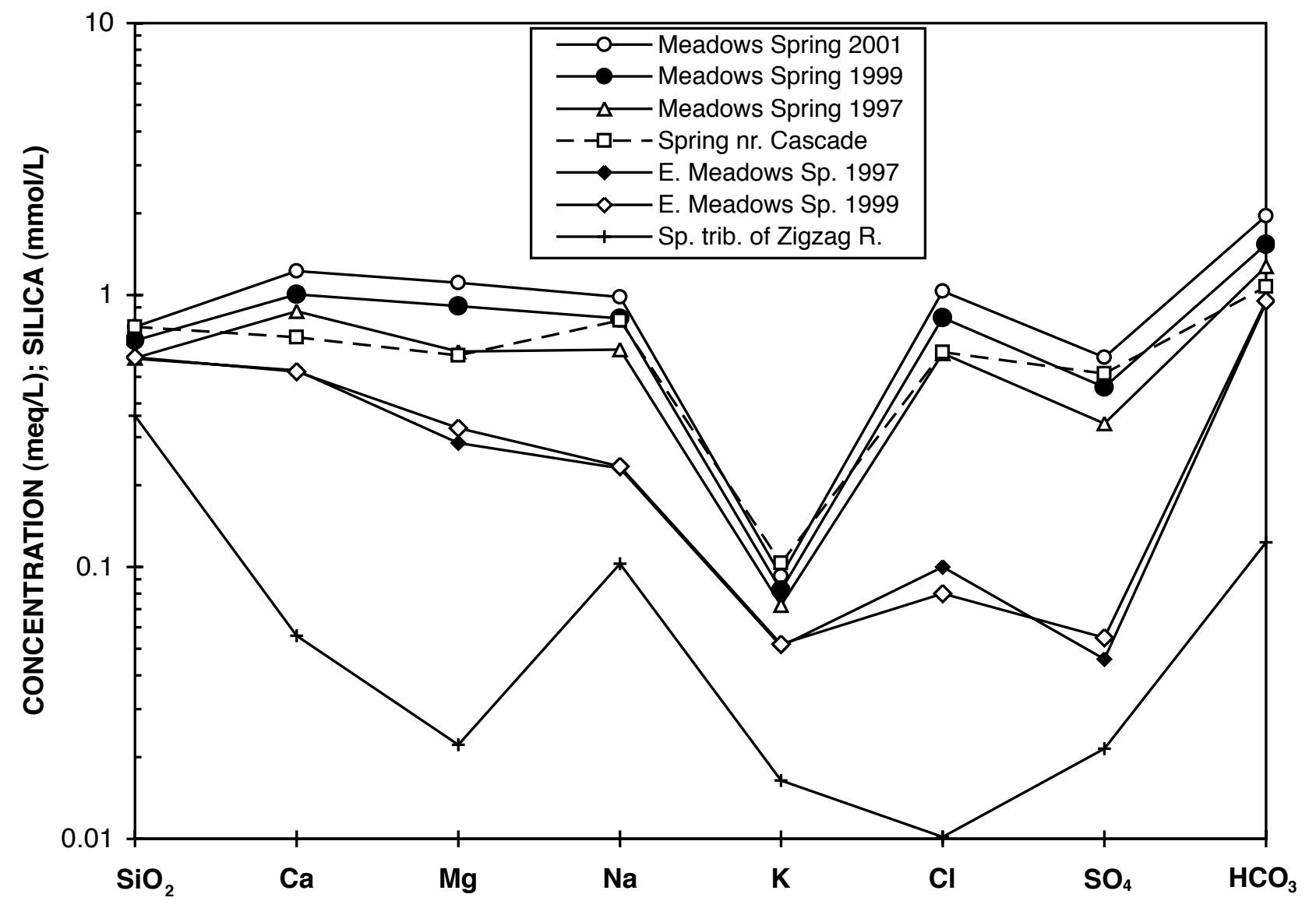

Figure 17. Modified Schoeller diagram (note log scale) for Meadows springs, spring near the Cascade, and spring tributary to the Zigzag River for reference. 


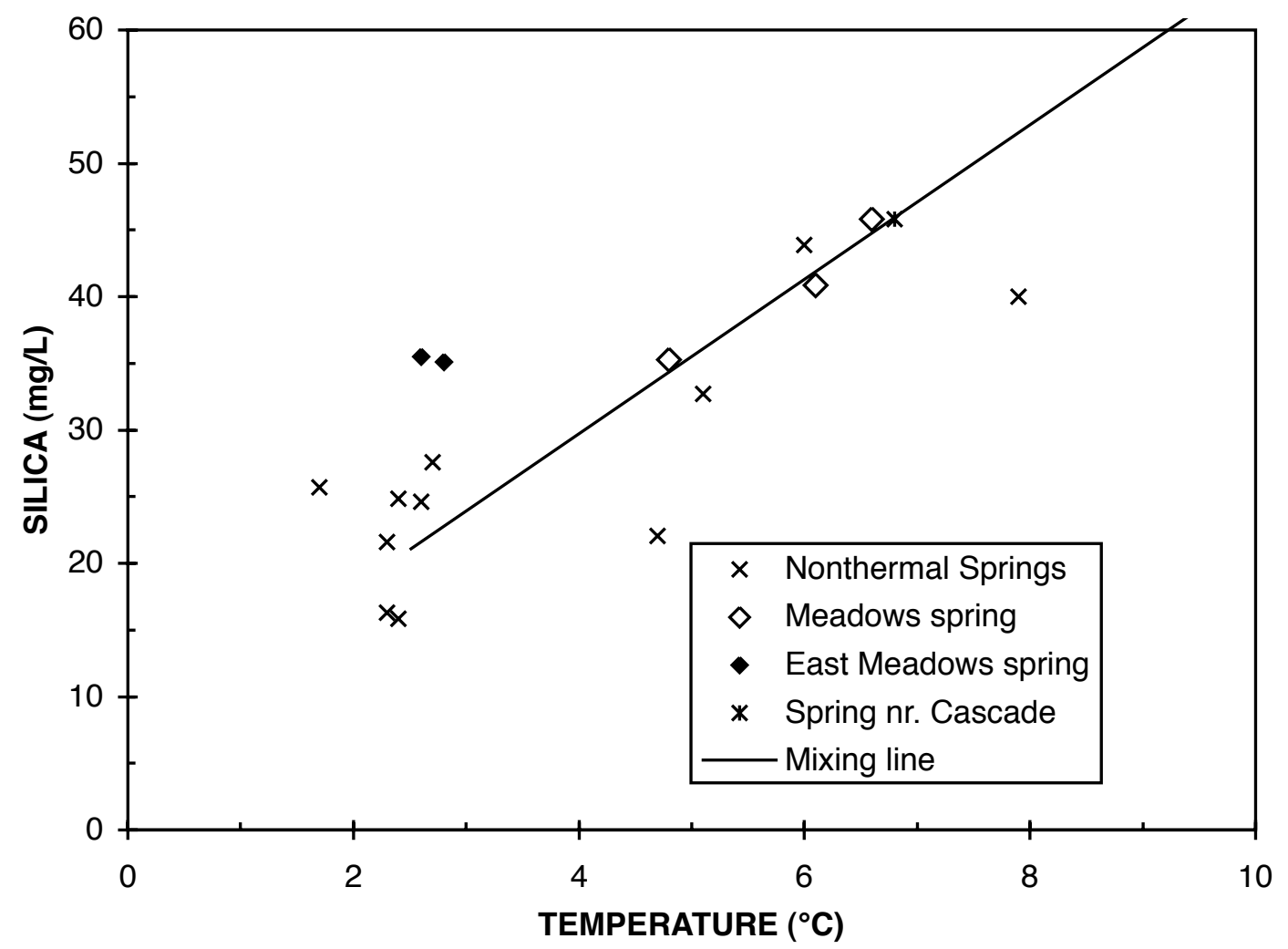

Figure 18. Silica versus spring temperature for Meadows springs, spring near the Cascade, and nonthermal springs. Mixing line is for Meadows Spring samples. 


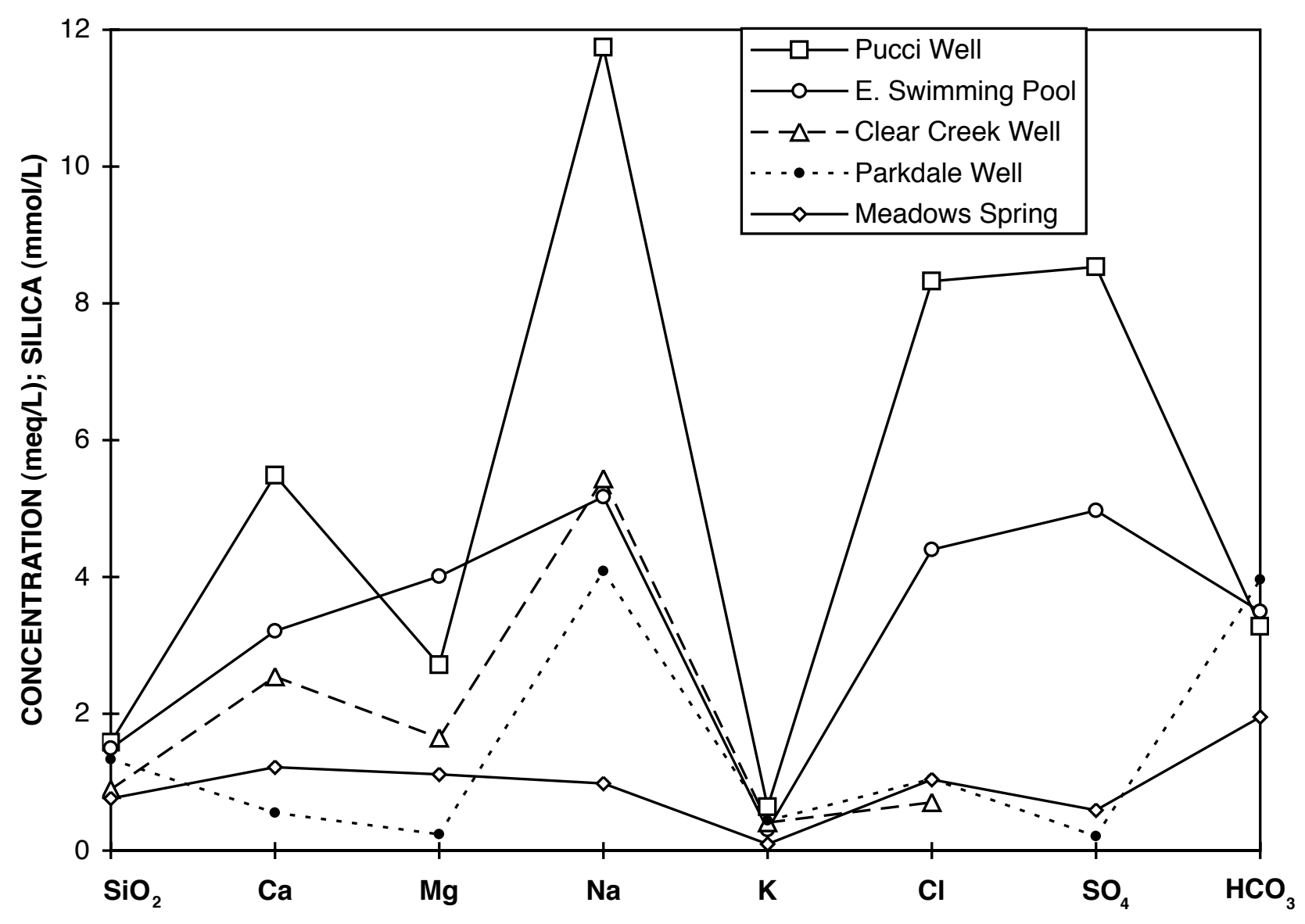

Figure 19. Modified Schoeller diagram for well samples and Swim Warm Springs (East Swimming Pool) and Meadows Spring. 